\title{
21. LATE QUATERNARY CLIMATICALLY RELATED PLANKTONIC FORAMINIFERAL ASSEMBLAGE CHANGES: HOLE 893A, SANTA BARBARA BASIN, CALIFORNIA ${ }^{1}$
}

\author{
James P. Kennett ${ }^{2}$ and Kathryn Venz ${ }^{3}$
}

\begin{abstract}
Planktonic foraminiferal assemblages are described quantitatively from Hole 893A, a continuous 196.5-m uppermost Quaternary sequence from Santa Barbara Basin, Southern California. A record of glacial/interglacial cycles is clearly exhibited by changes in planktonic foraminiferal assemblages during the last $\sim 160$ k.y. Faunal changes in the sequence record the northsouth movement of surface-water masses related to the changing relative strengths of the cool California Current and the warm Inshore Countercurrent (Davidson Countercurrent). Glacial maxima (Stages 2, 4, and 6) and late Stage 5 are associated with a Subarctic Assemblage when Subarctic waters had migrated to Southern California, south of Santa Barbara Basin. Average seasurface temperatures in the basin were then less than $10^{\circ} \mathrm{C}$. The warmest climatic episodes (Stage 1, or Holocene, and Substage $5 \mathrm{e}$, or Eemian) are both associated with the Transitional Assemblage, which occurs in present-day basinal surface-waters (average sea-surface temperature of $15^{\circ} \mathrm{C}$ ). The only prolonged climatic interval represented by assemblages intermediate between Subarctic and Transitional assemblages is Stage 3 ( 60 to $25 \mathrm{k} . \mathrm{y}$.). This interval is also marked by the highest temporal variability exhibited by the faunas during the last 160 k.y.. in turn reflecting strong climatic oscillations that have also been described in the Greenland Ice Sheet. It is inferred that during Stage 3, the southern boundary of Subarctic waters and the $10^{\circ} \mathrm{C}$ sea-surface isotherm lay close to the Santa Barbara region. Oscillations in the position of this faunal boundary thus produced the observed high variability in planktonic foraminiferal assemblages during this interval.

Comparisons with modern planktonic foraminiferal distributions suggest that average sea-surface temperatures in Santa Barbara Basin during glacial maxima were $\sim 7^{\circ}-8^{\circ} \mathrm{C}$ compared with $\sim 15^{\circ} \mathrm{C}$ during the warmest interglacial episodes, including the present time. The range in average sea-surface temperature between glacial to interglacial extremes in this region is thus $\sim 7^{\circ}-8^{\circ} \mathrm{C}$. Changes in planktonic foraminiferal assemblages during the last deglaciation ( 17 to $9 \mathrm{ka}$ ) assist in detailing aspects of climate change, including the Younger Dryas cool episode $(\sim 13$ to $11.1 \mathrm{ka})$. Cooling during the Younger Dryas was not of full glacial scale: sea-surface temperatures remained higher than $10^{\circ} \mathrm{C}$, but Subarctic waters remained close to the Southern California Borderland.

Relatively high abundances throughout the sequence of Globigerina bulloides, a form often considered to represent a proxy for oceanic upwelling, suggest that significant coastal upwelling continued to influence the Santa Barbara Basin throughout the latest Quaternary. This includes glacial times when lower sea levels reduced connections between the basin and the open ocean.
\end{abstract}

\section{INTRODUCTION}

This contribution describes quantitative changes in latest Quaternary planktonic foraminiferal assemblages in Ocean Drilling Program Hole 893A, a 196.5-m sediment sequence from Santa Barbara Basin, Southern California. Hole $893 \mathrm{~A}$ is located at $34^{\circ} 17.25^{\prime} \mathrm{N}$, $120^{\circ} 02.2^{\prime} \mathrm{W}$, in Santa Barbara Basin, $20 \mathrm{~km}$ south of the Santa Barbara coastline at a water depth of $576.5 \mathrm{~m}$ (Fig. 1A). This is the first continuously cored Quaternary sequence greater than $10 \mathrm{~m}$ thick from the Southern California Borderland Province, which is made up of a number of semi-enclosed basins marked by reduced circulation with the Pacific Ocean at intermediate water depths (Emery, 1962). As a result, basinal waters are typically low in oxygen, leading to the accumulation of organic carbon and anoxic mud. Site 893 was cored primarily to provide a late Quaternary-age marine paleoclimatic sequence at high stratigraphic resolution for this region of Pacific. Site 893 is one of the few sites in the world ocean in which sediments accumulated sufficiently rapidly $(\sim 160 \mathrm{~cm} / \mathrm{k} . \mathrm{y}$.) and with minimal disturbance to provide a high-resolution paleoclimatic record. Deep-sea carbonate sequences have much lower stratigraphic resolution be-

'Kennett. J.P., Baldauf, J.G., and Lyle, M. (Eds.), 1995. Proc. ODP. Sci. Results. 146 (Pt. 2): College Station. TX (Ocean Drilling Program).

-Marine Science Institute and Department of Geological Sciences, University of California, Santa Barbara, CA 93106, U.S.A.

${ }^{3}$ Department of Geology, University of Florida, Gainesville, FL 32611, U.S.A. cause of lower sedimentation rates $(\sim 2 \mathrm{~cm} / \mathrm{k} . \mathrm{y}$.) and greater biological mixing.

Santa Barbara Basin is a tectonic depression representing the submerged southwestern part of the Transverse Ranges Province. Terrigenous sediments are delivered from nearby continental sources to the north and south of the basin (Fig. IA). During the last glacial maximum when sea level was $121 \pm 5 \mathrm{~m}$ below the present-day level (Fairbanks, 1989), four of the Channel Islands merged into a single, large body of land known as Santa Rosae Island, transforming the Santa Barbara Channel into a narrow, sheltered body of water with more restricted circulation with the open Pacific Ocean (Fig. 1B). The basin consists of a very thick ( $>2000 \mathrm{~m}$ ), uncomplicated, flat-lying sequence of Quaternary sediments, of which only the topmost part was drilled for Site 893 . The basin has a maximum depth of $\sim 600 \mathrm{~m}$ and dysaerobic $(<0.1 \mathrm{~mL} / \mathrm{L}$ oxygen) bottom waters below about $500 \mathrm{~m}$. At the present time, this bottom water is replaced by low oxygen intermediate waters that flow over the sill from the Pacific Ocean. These waters flow into the basin via the oxygen minimum zone occurring at upper bathyal depths off the coast. This further reduces oxygen levels of bottom waters entering the basin. The small supplies of oxygen entering the basin are further depleted as a result of oxidation of abundant organic material derived from highly productive surface waters. Occasional partial turnover occurs at a rate that prevents total stagnation (Sholkovitz and Gieskes, 1971; Reimers et al., 1990). Santa Barbara Basin is the only basin in the California Borderland Province that exhibits persistent annual varves through most of the 
Figure 1. Location of Site 893 in Santa Barbara Basin. A. Present-day physiography. B. Last glacial maximum physiography, when sea level was $120 \mathrm{~m}$ lower than the present (Fairbanks. 1989).
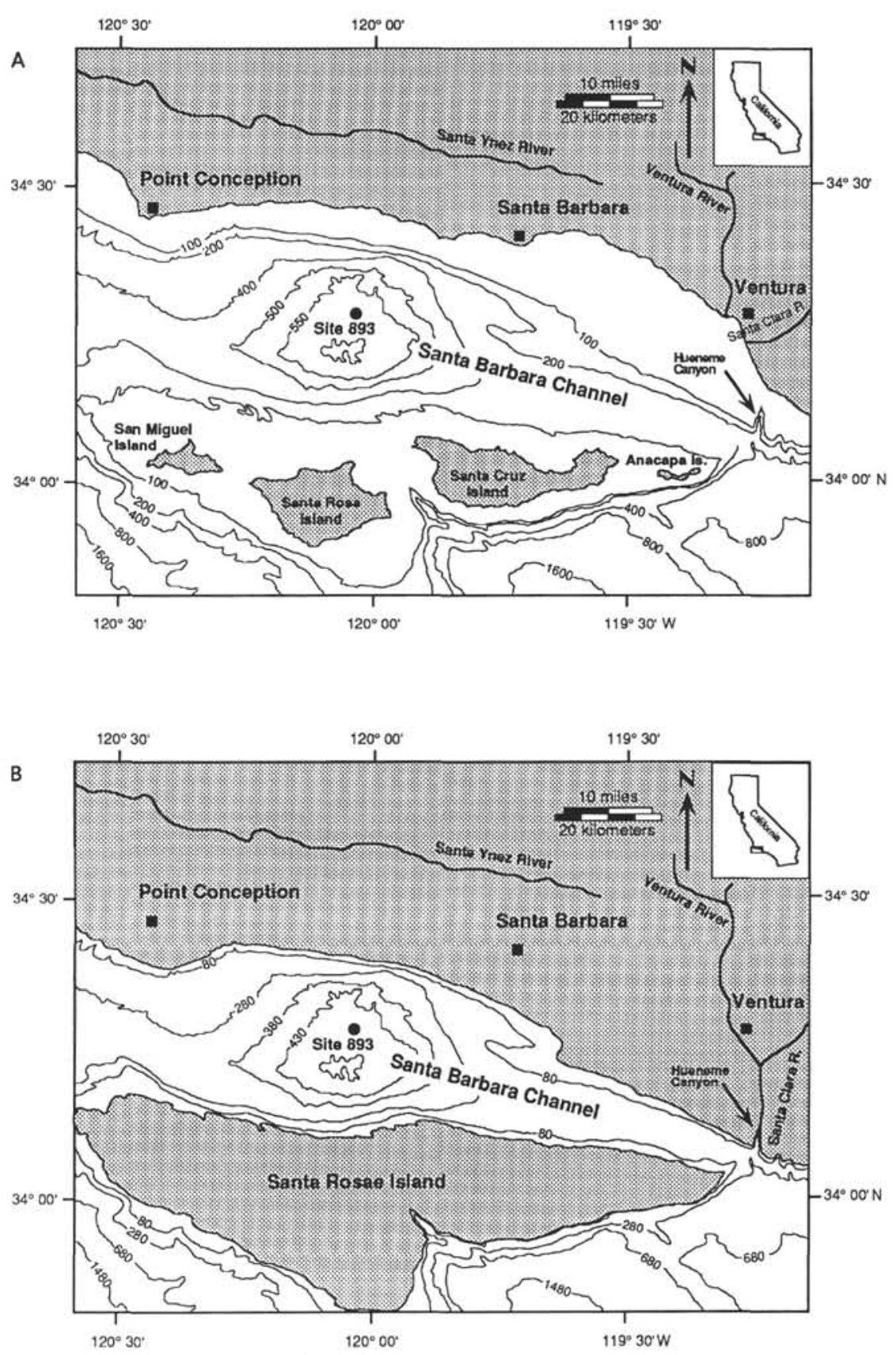

Holocene, in part reflecting an almost complete lack of oxygen in its bottom waters and resulting lack of burrowing organisms.

The upper Quaternary sequence at Site 893 represents deposition at high sedimentation rates $(\sim 160 \mathrm{~cm} / \mathrm{k} . \mathrm{y}$.) in suboxic to oxic conditions and contains diatoms, radiolarians, foraminifers, and pollen in sufficient abundance, thus providing an important opportunity for high-resolution late Quaternary paleoclimatic/paleoceanographic investigations (Kennett, Baldauf, et al., 1994). In combination with high sedimentation rates it is possible to resolve decadal paleoclimatic changes and even subannual to annual climatic change in those parts of the sequence where annual laminae are preserved.

The Santa Barbara Basin sediment sequence is well located to sensitively record global climate changes that occurred during the Quaternary. The dominant hydrographic features that have influenced the Santa Barbara Basin are (1) southward flowing, cold Cali- fornia Current; (2) northward flowing, warmer, surface Inshore Countercurrent (Davidson Current) and subsurface countercurrent (California Undercurrent); and (3) associated coastal and offshore upwelling systems (Huyer, 1983; Lynn and Simpson, 1987; Simpson and Lynn, 1990; Hickey, 1992). The character and distribution of these currents are determined by ocean-atmosphere interactions over broad areas of the Pacific Ocean (Reid et al., 1958; Douglas, 1981; Simpson and Lynn, 1990). It has long been established that major variations in late Cenozoic molluscan and foraminiferal assemblages throughout the Pacific Coast of North America have, in large measure, been in response to migrating isotherms associated with global climate cycles (Durham, 1950; Addicott, 1969; Ingle, 1967, 1973). Indeed global climatic oscillations are often sensed most sharply at mid-latitude locations and most especially within areas of eastern boundary currents (Ingle, 1973), as in Southern California. During 
the late Quaternary a number of studies have shown that California Current circulation intensified and expanded southward and that tropical waters retreated during the last glacial maximum compared with today (Moore, 1973, 1978; CLIMAP Project Members, 1981; Molina-Cruz, 1988). At present the California Current is primarily a near-surface $(0-300 \mathrm{~m})$ current, the core of which is located 300 to $400 \mathrm{~km}$ offshore (Lynn and Simpson, 1987). Mesoscale eddies associated with the California Current transfer cold surface waters to California coastal regions including Santa Barbara Basin (Simpson and Lynn, 1990). In the present day a dominant feature of the surface circulation in Santa Barbara Basin is a semipermanent cyclonic gyre that incorporates water from both the northwest and southeast. The seasonal cycle of flow within the California Current system in the California Bight and regions to the north is marked by the seasonal appearance of the Davidson Current and by intensification of the California Undercurrent. Where the subsurface poleward flow reaches shallow levels $(<50 \mathrm{~m})$ it is almost indistinguishable from the surface Inshore Countercurrent (Lynn and Simpson, 1987).

Seasonal variations in the strength of the California Current and the countercurrents that affect Santa Barbara Basin are primarily responses to changes in wind strength and direction. Northerly winds are generally strongest between April and August (spring and summer), causing strong flow of the cold California Current toward the south, and associated weak cyclonic flow of cold waters into Santa Barbara Basin. Conversely, from December to February, when the northerly winds weaken, the Davidson Current is stronger and a net poleward surface transport of warm waters occurs along the coast ( $\mathrm{Pi}$ sias, 1978; Lynn and Simpson, 1987).

Coastal upwelling is a pervasive feature off the west coast of North America. This upwelling of subsurface waters results from offshore Ekman transport of surface waters away from the continent due to equatorward winds along the coast (e.g., Huyer, 1983). Active upwelling is largely restricted to a narrow band $(\sim 10-25 \mathrm{~km}$ wide) along the entire coast, although the region influenced by upwelling appears to be much wider. Coastal upwelling is relatively weak in the Santa Barbara Basin region because of a zonal coastline and weaker winds (Huyer, 1983). Nevertheless, nutrient-rich waters are transported into the basin in eddies from the important coastal upwelling zone located seaward of Point Conception. Near Point Conception, eddy mixing occurs between the coastal upwelling zone (within 50 $\mathrm{km}$ of the coast) and the offshore oceanic regime associated with the core of the California Current. This seems to result from interaction between the bathymetry and the poleward-flowing California Undercurrent (Simpson and Lynn, 1990).

Seasonal changes in the strength and direction of the winds influence the intensity of upwelling near Point Conception and, in turn, biological productivity in Santa Barbara Basin. Strong upwelling episodes occur from late spring to early summer. Individual upwelling episodes lasting up to three weeks vary according to the strength of the northerly winds (Bakun, 1975; McGowan, 1984; Eppley, 1986; Atkinson et al., 1986). The upwelled water is cold, oxygen poor, and nutrient rich in comparison with the surface waters. The upwelling of cold waters during summer and the increased northward flow in winter of the relatively warm Davidson Current reduces the annual temperature range in the surface waters, although this is still high at $12^{\circ} \mathrm{C}$ (Pisias, 1979).

Periods of intensification of the Davidson Current are related to El Niño Southern Oscillation (ENSO) events that affect the entire eastern Pacific and typically occur at intervals of $\sim 5$ to $7 \mathrm{yr}$ (Enfield and Allen, 1980; Robles and Marinone, 1987). In the region of Santa Barbara Basin, these warm events coincide with episodes of decreased plankton productivity and reduced southerly flow of the California Current (Eppley, 1986). The warmer events are commonly associated with anomalously high rainfall in Southern California (Namias, 1969).

Previous paleoclimatic studies of the late Quaternary of Santa Barbara Basin were restricted to the Holocene $(<\sim 9$ ka). Dunbar
(1983) produced a high-resolution planktonic foraminiferal (Globigerina bulloides) oxygen isotopic record for the last $230 \mathrm{yr}$ from a box core. This record closely correlates with the historical record of sea-surface temperature in the region since 1870. The amplitude of the oxygen isotopic signal is large $(1.5 \%)$ and partly reflects the large temporal and seasonal variability of sea-surface temperatures caused by upwelling and ENSO events. However, Dunbar (1983) noted that the isotopic range is greater than expected from historical temperature records, because it is amplified by seasonal and/or annual differential production of $G$. bulloides. A number of other investigations on the Santa Barbara Basin cores have dealt with the paleoclimatic history at high-resolution within the last $300 \mathrm{yr}$ (Soutar and Crill, 1977; Weinheimer et al., 1986; Schimmelmann and Tegner, 1991).

Only two studies of sediments of Santa Barbara Basin focused on paleoclimatic records on time scales of $1000 \mathrm{yr}$ or greater, although both are limited to the Holocene. No previous paleoclimatic studies have quantitatively examined planktonic foraminiferal assemblages of latest Quaternary age in the basin. However, other microfossil groups have been employed. Pisias $(1978,1979)$ documented a paleoclimatic-paleoceanographic record of radiolarian-based sea-surface temperatures for the past $8000 \mathrm{yr}$. This study suggested a history of significant paleoclimatic/paleoceanographic changes during the Holocene. Heusser (1978) documented Holocene terrestrial climate changes based on changes in pollens and spores in a core from Santa Barbara Basin. This work suggests that the climate in the area from 8 to $5.4 \mathrm{ka}$ was dominantly warm subtropical and humid. Warm seasurface temperatures, increased rainfall, and reduced southerly flow of the California Current indicated by these studies suggest a prolonged period that is ENSO-like in character. Since $5.4 \mathrm{ka}$, the area has undergone significant paleoclimatic fluctuations including strengthening of the California Current system (Pisias, 1978). Paleotemperature estimates based on changes in radiolarian assemblages in Santa Barbara Basin suggest a maximum range of $12^{\circ} \mathrm{C}$ (February) during the Holocene, which is close to a recorded range of $11^{\circ} \mathrm{C}$ for a 25-yr period from 1952 to 1977 (Pisias, 1978, 1979).

The principal changes in planktonic foraminiferal assemblages during latest Quaternary glacial/interglacial oscillations in Southern California are well known from studies of piston cores (Bandy, 1968; Ingle, 1967). A relatively diverse fauna dominated by dextral-coiled Neogloboquadrina pachyderma is characteristic of modern assemblages and those of the Holocene interglacial. In distinct contrast, the last glacial episode is marked by assemblages of lower diversity dominated by sinistral-coiled $N$. pachyderma. Planktonic foraminiferal assemblages of the last glacial episode in Southern California are typical of the modern Subarctic Pacific. In addition to sinistral N. pachyderma this assemblage contains Globigerina bulloides, Globigerina quinqueloba and Globigerinita uvula in relatively low abundances. This is the Subarctic Pacific Assemblage (Bradshaw, 1959; Bandy, 1968, 1969; Bé, 1977; Reynolds and Thunell, 1985; Ortiz and Mix, 1992).

In spite of the mid-latitude location at $34^{\circ} \mathrm{N}$, modern and Holocene planktonic foraminiferal assemblages in Santa Barbara Basin are cool temperate in character because of the influence of the cool, southward-flowing California Current and offshore upwelling of cool intermediate waters. In the offshore area near Point Conception, to the west of Santa Barbara Basin, surface-water temperatures of $10.2^{\circ} \mathrm{C}$ have been reported at centers of upwelling, whereas intervals of nonupwelling in the same area are marked by temperatures as high as $14^{\circ}-15^{\circ} \mathrm{C}$ (Atkinson et al., 1986). The typical present-day seasonal sea-surface (mixed-layer) temperature range in Santa Barbara Basin is $\sim 12^{\circ} \mathrm{C}$ to $17^{\circ} \mathrm{C}$ (average $12^{\circ} \mathrm{C}$ ). During ENSO episodes, which occur every several years, sea-surface temperatures may rise to $20^{\circ} \mathrm{C}$ and subtropical planktonic assemblages are more strongly transported to Santa Barbara Basin. Modern planktonic foraminiferal assemblages in Santa Barbara Basin are dominated by dextral-coiled $N$. pachyderma, Globigerina bulloides, and Globigerina quinqueloba. Also represented are Neogloboquadrina dutertrei, Globorotalia in- 
flata, Globorotalia truncatulinoides (sinistral), Globigerinoides ruber, Orbulina universa, and a few others. This is the Transitional Assemblage (Bradshaw, 1959; Bandy, 1968). Globigerina bulloides and Globigerina quinqueloba are also important elements of the Subarctic assemblage.

In the present northeast Pacific, the boundary between the Subarctic and Transitional assemblages is considered to be between $\sim 40^{\circ}-$ $45^{\circ} \mathrm{N}$, off the coasts of Oregon and Washington (Bradshaw, 1959) and coincides with the Polar Front or Subarctic Convergence. This is equivalent to the Subpolar Front $\left(40^{\circ}-55^{\circ} \mathrm{N}\right)$ of Roden (1977). Southward-flowing California Current waters presently originate in the transition zone south of the Subpolar Front near $50^{\circ} \mathrm{N}$. North of the Subpolar Front, geostrophic flow is cyclonic, and hence northward along the continental margin. According to Bradshaw (1959), the faunal boundary between Subarctic and Transitional assemblages is associated with a switch from dominantly sinistral to dextral-coiled populations of $N$. pachyderma, and coincides with the $9^{\circ} \mathrm{C}$ to $11^{\circ} \mathrm{C}$ summer isotherm in the northeast Pacific (Smith, 1964; Bandy, 1968, 1969; Ingle, 1967). In the northeast Pacific, Reynolds and Thunell (1986) found that the switch from dominantly sinistral to dominantly dextral-coiled $N$. pachyderma occurred at $\sim 8^{\circ} \mathrm{C}$. However, their later work (Sautter and Thunell; 1989) showed that temperature-faunal relationships are more complex. Since $N$. pachyderma is a deeperdwelling mixed-layer species (Fairbanks and Wiebe, 1980; Fairbanks et al., 1982), it may not accurately record temperature changes at the sea surface (Sautter and Thunell, 1989). Nevertheless, it is clear that a general relation exists between ocean temperature and the switch between dominantly sinistral and dextral-coiled populations of $N$. pachyderma. Sautter and Thunell (1991) indicate that the preferred temperature range of dextral-coiled $N$. pachyderma, inferred from oxygen and carbon isotopic measurements of specimens from the Southern California Bight, to be between $10^{\circ}$ and $15^{\circ} \mathrm{C}$. Although there is still no consensus on the exact temperature of the coiling switch, for the purposes of this paper we assume $10^{\circ} \mathrm{C}$.

Detailed relations between the assemblage changes and the water mass boundary are also not well known. In the modern ocean, the Subarctic Assemblage exists both north of the Subpolar Front (Sautter and Thunell, 1989) and south of the front in transitional waters off southern Oregon (Ortiz and Mix, 1992). This is because surface-water temperature changes are related to both the changing strength of the California Current and increased upwelling that brings cold waters to the ocean surface (Ortiz and Mix, 1992). Related strong oceanographic gradients cause large changes in planktonic foraminiferal assemblages progressing offshore from Oregon across the California Current. In this region, sinistral-coiled $N$. pachyderma is relatively abundant near the coast due to the combined influences of the Subarctic Water Mass and intensified coastal upwelling (Ortiz and Mix, 1992).

Abundant populations of sinistral-coiled N. pachyderma $(90 \%$ to $100 \%$ sinistral) occur at temperatures lower than the $\sim 6^{\circ} \mathrm{C}$ summer isotherm (Bandy, 1968; Bé, 1973). In the Antarctic region, sediment assemblages highly dominated by sinistral-coiled $N$. pachyderma (> 90\%) occur south of the Polar Front and the $4^{\circ} \mathrm{C}$ summer sea-surface isotherm (Kennett, 1968). Assemblages dominated by dextralcoiled N. pachyderma and associated forms are bounded by the $10^{\circ} \mathrm{C}$ and $20^{\circ} \mathrm{C}$ summer surface-water isotherms (Kennett, 1976).

Studies of planktonic foraminiferal assemblages captured in a sediment trap deployed in San Pedro Basin in the California Borderland southeast of Santa Barbara Basin suggest a seasonal succession of species occurs during the year (Sautter and Thunell, 1991; Sautter and Sancetta, 1992). Although based on a short time series, the data suggest that seasonal species dominance changes from $G$. bulloides in the winter to dextral-coiled $N$. pachyderma and G. quinqueloba in the spring (April) to $G$. bulloides during upwelling and to $N$. dutertrei immediately following upwelling. A summer assemblage that includes $G$. ruber appears as surface waters become strongly stratified.
Studies over a longer time period may reveal a more complex history of seasonal species succession.

\section{STRATIGRAPHY AND CHRONOLOGY}

The upper Quaternary sequence at Hole 893A is largely hemipelagic mud composed primarily of olive gray silt and clay with minor quantities of diatoms, foraminifers, and calcareous nannofossils (Kennett, Baldauf, et al., 1994). The sequence consists of well-laminated to nonlaminated (massive) sediments, representing deposition in low-oxygen to oxygenated environments, respectively. Two broadly similar sedimentary cycles comprise the entire $200-\mathrm{m}$ sequence. Each consists of a lower, intermittently laminated interval passing upward with decreasing abundance of laminations into a relatively thin $(15 \mathrm{~m})$ homogeneous interval. This homogeneous inter$\mathrm{val}$ is then succeeded abruptly by a relatively thin $(\sim 15-25 \mathrm{~m})$ interval of almost continuously well-laminated sediment (Kennett, Baldauf, et al., 1994). Sand beds are relatively rare in the core and are almost completely absent in the well-laminated intervals.

Oxygen isotopic stratigraphy of Hole 893A (Kennett, this volume) and pollen analysis (Heusser, this volume) indicate that the sequence ranges from near the base of Oxygen Isotope Stage 6 ( 160 ka) to the present day. The sequence, therefore, includes two glacial maxima (Stages 6 and 2) and two interglacial episodes (Stages 5 and 1).

An age model for the upper $43 \mathrm{mbsf}$ of Hole 893A was developed using a total of 17 accelerator mass spectrometric (AMS) radiocarbon ages of planktonic foraminiferal samples (Ingram and Kennett, this volume). This represents the last $28.9 \mathrm{ka}$. The ${ }^{14} \mathrm{C}$ ages younger than 10.6 ka have been calibrated to calendar years following Stuiver and Braziunas (1993) and for older samples following Bard et al. (1990). Also, a correction of $825 \mathrm{yr}$ has been applied for the local ocean reservoir age (Ingram and Kennett, this volume).

The Hole 893A sequence at greater depth has been dated using oxygen isotope events (Kennett, this volume) and a paleoclimatic curve based on changes in pollen assemblages (Heusser, this volume). Unambiguous paleoclimatic events recorded in Hole 893A have been correlated with the standard deep-sea oxygen isotope chronology (Martinson et al., 1987) as follows: Stage 3.3, $73.89 \mathrm{~m}$; Stage 4.23, 90.49 m; Stage 5e/5d, $140.69 \mathrm{~m}$; Stage 5.5 (5e), $147.46 \mathrm{~m}$; Termination II (Stage 6/5), $156.87 \mathrm{~m}$; Stage 6.41, $195.00 \mathrm{~m}$. Assignments of sediment thickness in the core were corrected for all gaps (voids) resulting from sediment displacement due to gas expansion (Merrill and Rack, this volume). Ages for all levels deeper than 43 mbsf were calculated using linear interpolation between each of the datums employed (Kennett, this volume). All foraminiferal data are plotted against calendar years.

The chronological spacing of the foraminiferal samples in Site $893 \mathrm{~A}$ is every $\sim 450$ years for the last $20 \mathrm{ka}$ and every $\sim 1000 \mathrm{yr}$ for older intervals. Each sample represents an interval of $\sim 20$ to 30 years.

\section{MATERIALS AND METHODS}

Samples of $10 \mathrm{~cm}^{3}$ volume were taken at moderately high stratigraphic resolution from Hole $893 \mathrm{~A}$ for foraminiferal investigations. These are at $\sim 50-\mathrm{cm}$ intervals in the upper $25 \mathrm{~m}$ and $\sim 100-$ to $150-\mathrm{cm}$ intervals for the remaining section. The raw samples were oven dried at $50^{\circ} \mathrm{C}$, disaggregated using warm water, washed over a $63-\mu \mathrm{m}$ sieve, and oven dried at $50^{\circ} \mathrm{C}$. In most cases more than 300 (minimum of $\sim 250$ ) specimens of planktonic foraminifers were counted in the $>150-\mu \mathrm{m}$ fraction in a total of 119 samples, and the percentage calculated. A small proportion $(<15 \%)$ of the samples lacked sufficient numbers of planktonic foraminifers for census work. Samples from the lowermost $5 \mathrm{~m}$ (below $\sim 191$ ) of Hole $893 \mathrm{~A}$ are almost bar- 

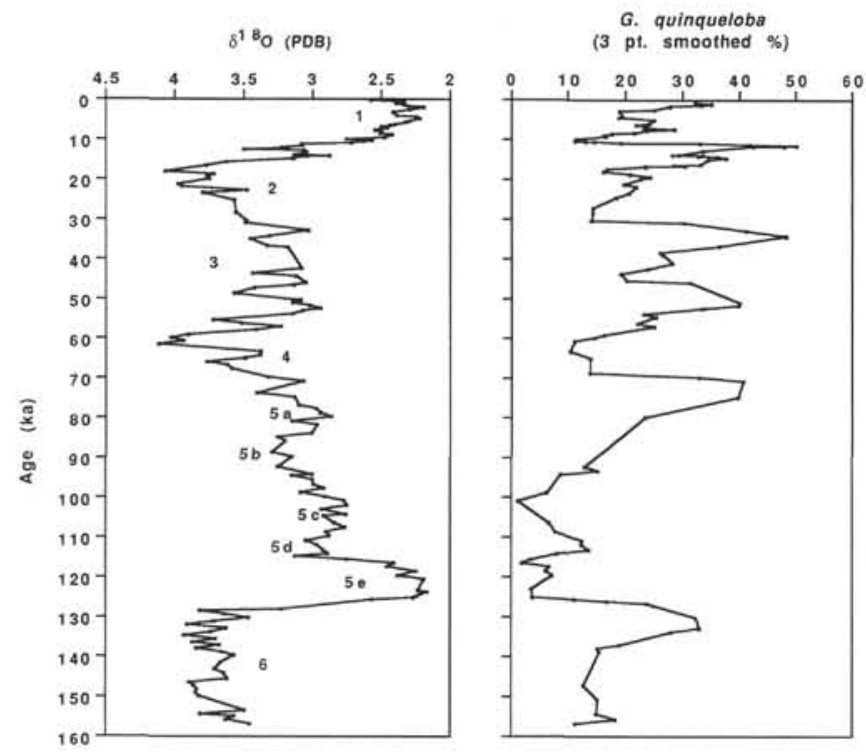

Figure 2. Percent frequency changes with age (ka) of Globigerina quinqueloba (smoothed using 3-point running average) within planktonic foraminiferal assemblages compared with oxygen isotopic stratigraphy (Kennett, this volume) in Hole 893A. The assignment of oxygen isotopic stages also indicated.

ren of foraminifers. Low abundance is probably the result of insufficiently high productivity of planktonic foraminifers during the brief (20-30 yr) interval represented by each sample.

\section{RESULTS}

Planktonic foraminiferal assemblages, where present, are well preserved and do not appear to have been strongly affected by dissolution. The relatively delicate forms $G$. bulloides and $G$. quinqueloba occur throughout, also suggesting that dissolution was generally not severe. Studies of planktonic foraminiferal assemblages caught in a sediment trap in San Pedro Basin (Sautter and Thunell, 1991) indicate a quantitative dominance of these two forms over N. pachyder$m a$, and they therefore should also dominate in sediment assemblages. This is not the case, which led Sautter and Thunell (1991) to suggest that ocean-floor assemblages have been strongly modified by dissolution. A persistent dominance of $N$. pachyderma in Hole 893A therefore may also reflect the importance of dissolution on the planktonic foraminiferal assemblages. Nevertheless, G. quinqueloba is present in relatively high abundances throughout the sequence, except during much of Stage 5 (Fig. 2), suggesting that faunal composition has not been primarily controlled by dissolution.

Interglacial planktonic foraminiferal assemblages in Hole 893A, present in the Holocene (Stage 1) and isotope Substage 5e, are moderately diverse, and are represented by a total of 16 species. Individual samples contain up to $\sim 12$ species (Table 1). By far, the most dominant form is dextral-coiled N. pachyderma, which exhibits percentage frequencies ranging from $\sim 40 \%$ to $80 \%$. The other most common species are G. bulloides and G. quinqueloba. The remaining species occur in relatively low frequencies. Of these, the most persistent forms occurring in the sequence are sinistral-coiled $N$. pachyderma, G. umbilicata, N. dutertrei, G. scitula, G. ruber, O. universa and G. glutinata.

Glacial assemblages are usually dominated by a single-form sinistral-coiled $N$. pachyderma, whereas G. quinqueloba and G. bulloides are common to abundant (Table 1). Dextral-coiled $N$. pachyderma may be present in variable abundances, although the coolest assemblages contain few individuals. Other forms consistently present are $G$. umbilicata and $G$. scitula, whereas the occurrence of G. glutinata is sporadic. Other forms typical of interglacial assemblages are generally absent.

Species frequency oscillations of the most abundant planktonic foraminiferal taxa in Hole 893A are plotted against depth in Figures 3 and 4 and against age in Figures 2, 5, and 6. The distributions of paleoclimatically useful taxa that occur in relatively low abundances are shown in Figure 7.

Neogloboquadrina pachyderma (dextral-coiling) (Figs. 2 and 4) exhibits frequency oscillations that switch abruptly between two extremes; $<10 \%$ to $>\sim 50 \%$. Few samples exhibit intermediate values. This species is the dominant form during intervals of peak warmth represented by interglacial Stage I and Substage 5e. During these intervals dextral-coiled $N$. pachyderma makes up between $\sim 40 \%$ and $80 \%$ of the assemblage. The relative abundance of this form is consistently highest during Substage 5e (Fig. 3) where it forms from $60 \%$ to $80 \%$ of the assemblage. This compares with Stage I, where it generally forms from $40 \%$ to $65 \%$ of the assemblage. Variation in relative abundances of this form is greater in Stage 1 than in Substage 5e. During all other intervals dextral-coiled $N$. pachyderma generally exhibits frequencies lower than $10 \%$. Brief intervals with higher relative abundances are associated with interstadial Stage 3.

Neogloboquadrina pachyderma (sinistral coiling) (Figs. 3 and 5), a polar to subpolar species, exhibits frequency variations generally opposite to those of dextral-coiled $N$. pachyderma. During intervals of peak warmth (Stage 1 and Substage 5e) this species is unimportant in the assemblage $(<\sim 5 \%)$. Most other intervals exhibit much higher relative abundances $(>50 \%)$, although large variation ( $10 \%$ to $95 \%)$ was observed. Apart from the warmest intervals, the changes in relative abundance of sinistral-coiled $N$. pachyderma are not clearly related to the isotopic paleotemperature changes. The coldest intervals are not represented by higher relative abundances of this form, nor are the warmest intervals marked by generally lower abundances. For example, much of Stage 5 ( $5 \mathrm{c}$ to $5 \mathrm{a}$ ) is marked by relatively high frequencies $(>60 \%)$ of sinistral-coiled $N$. pachyderma, rather than lower percentages as might be expected. Likewise, intervals of glacial extremes (Stages 2 and 4 ) are not associated with higher relative abundances of this form.

$N$. pachyderma assemblages also exhibit switches in coiling direction that generally mirror changes in percent frequency of this species (Figs. 3 and 5). The coiling ratios switch between two extremes: $<10 \%$ dextral to $>90 \%$ dextral. Assemblages marked by percent dextral-coiling less than $5 \%$ to $10 \%$ are associated with Stages 2,4 , and 6 and much of Stage 5, whereas assemblages exhibiting $>90 \%$ to $95 \%$ dextral-coiling are associated only with Stage 1 and Substage 5 e. Stage 3 is associated with large fluctuations in coiling ratios $(\sim 4 \%$ to $90 \%$ dextral-coiling). This is the only interval with coiling ratio values intermediate between the two extremes. Thus, apart from intervals within Stage 3, dextral forms dominate only during peak interglacial episodes.

Globigerina quinqueloba percent frequency variations are large $(\sim 2 \%$ to $70 \%)$ and highly variable (Figs. 2 and 4$)$. These changes show no consistent relations with the oxygen isotopic climatic record. In general, peak values of this species are associated with transitions between glacial and interglacial episodes $(6 / 5,5 / 4,3 / 2$, and $2 / 1)$. The lowest consistent values $(3 \%-15 \%)$ are associated with Stage 5. However, values are much higher $(\sim 10 \%-40 \%)$ in Stage 1.

Globigerina bulloides likewise exhibits high variability in relative abundances with maximum frequencies of $50 \%$ (Figs. 4 and 6). No clear relations exist between this variability and the climatic oscillations based on oxygen isotopic changes.

Globigerinoides ruber is a warm subtropical species occurring in low frequencies $(<4 \%)$ especially during relatively warm intervals in Hole 893A (Fig. 7). The most consistent occurrences of G. ruber are 
Table 1. Census data (raw counts) of planktonic foraminiferal species in samples from Hole 893A.

\begin{tabular}{|c|c|c|c|c|c|c|c|c|c|c|c|c|c|c|c|c|c|c|c|}
\hline $\begin{array}{l}\text { Core, section. } \\
\text { interval }(\mathrm{cm})\end{array}$ & $\begin{array}{l}\text { Depth } \\
\text { (mbsf) }\end{array}$ & $\begin{array}{l}\text { Age } \\
\text { (ka) }\end{array}$ & 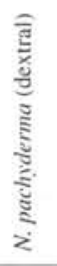 & 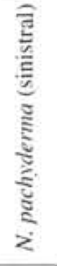 & 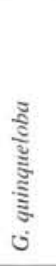 & نั & 离 & 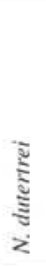 & 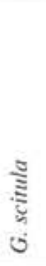 & $\begin{array}{l}\grave{\Xi} \\
\vdots\end{array}$ & 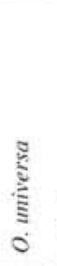 & 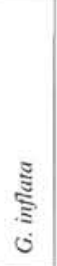 & 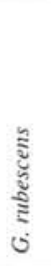 & 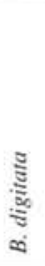 & 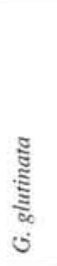 & हूँ & 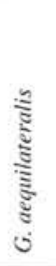 & 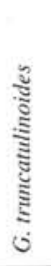 & $\begin{array}{l}\text { Total } \\
\text { counts }\end{array}$ \\
\hline $\begin{array}{l}146-893 \mathrm{~A}- \\
1 \mathrm{H}-1.11-13 \\
1 \mathrm{H}-1,55-57 \\
1 \mathrm{H}-2,5-7 \\
1 \mathrm{H}-2,55-57 \\
1 \mathrm{H}-2,105-107 \\
\end{array}$ & $\begin{array}{l}0.11 \\
0.55 \\
1.53 \\
2.03 \\
2.53\end{array}$ & $\begin{array}{l}0.023 \\
0.280 \\
0.828 \\
1.117 \\
1.410\end{array}$ & $\begin{array}{l}159 \\
141 \\
193 \\
198 \\
166\end{array}$ & $\begin{array}{r}32 \\
10 \\
12 \\
11 \\
5\end{array}$ & $\begin{array}{r}78 \\
80 \\
116 \\
138 \\
110 \\
\end{array}$ & $\begin{array}{r}31 \\
66 \\
7 \\
10 \\
22 \\
\end{array}$ & $\begin{array}{l}6 \\
9 \\
: \\
.\end{array}$ & $\begin{array}{l}2 \\
1 \\
1 \\
3 \\
\end{array}$ & $\begin{array}{l}1 \\
3 \\
4 \\
3 \\
6 \\
\end{array}$ & $\begin{array}{r}3 \\
4 \\
2 \\
7 \\
12 \\
12\end{array}$ & $\begin{array}{l}1 \\
1 \\
3 \\
3 \\
2\end{array}$ & $:$ & $\vdots$ & $\vdots$ & $\begin{array}{l}i \\
2 \\
4\end{array}$ & i & : & : & $\begin{array}{l}313 \\
316 \\
334 \\
376 \\
327 \\
\end{array}$ \\
\hline $\begin{array}{l}1 \mathrm{H}-3,5-7 \\
1 \mathrm{H}-4,5-7 \\
1 \mathrm{H}-4,55-57 \\
2 \mathrm{H}-1.55-57 \\
2 \mathrm{H}-1.105-107\end{array}$ & $\begin{array}{l}3.04 \\
4.55 \\
5.05 \\
7.04 \\
7.54 \\
\end{array}$ & $\begin{array}{l}1.713 \\
2.625 \\
2.932 \\
4.168 \\
4.482\end{array}$ & $\begin{array}{l}187 \\
166 \\
212 \\
168 \\
154\end{array}$ & $\begin{array}{r}9 \\
3 \\
20 \\
9 \\
23 \\
\end{array}$ & $\begin{array}{l}95 \\
55 \\
98 \\
34 \\
75 \\
\end{array}$ & $\begin{array}{l}12 \\
25 \\
32 \\
51 \\
43\end{array}$ & $\begin{array}{r}6 \\
4 \\
14 \\
7 \\
\end{array}$ & $\begin{array}{l}. \\
7 \\
7 \\
5\end{array}$ & $\begin{array}{r}8 \\
3 \\
10 \\
7 \\
16 \\
\end{array}$ & $\begin{array}{r}10 \\
1 \\
1 \\
3 \\
4 \\
\end{array}$ & $\begin{array}{l}i \\
3 \\
i\end{array}$ & i & i & i & $\begin{array}{l}3 \\
i\end{array}$ & $\begin{array}{r}7 \\
4 \\
10 \\
10 \\
\end{array}$ & i & : & $\begin{array}{l}322 \\
269 \\
387 \\
306 \\
342 \\
\end{array}$ \\
\hline $\begin{array}{l}2 \mathrm{H}-2,55-57 \\
2 \mathrm{H}-3,55-57 \\
2 \mathrm{H}-2,105-107 \\
2 \mathrm{H}-4,5-7 \\
2 \mathrm{H}-4,105-107\end{array}$ & $\begin{array}{r}8.55 \\
9.97 \\
10.47 \\
10.91 \\
11.77\end{array}$ & $\begin{array}{l}5.120 \\
6.025 \\
6.345 \\
6.628 \\
7.183\end{array}$ & $\begin{array}{l}150 \\
206 \\
160 \\
184 \\
257\end{array}$ & $\begin{array}{r}13 \\
7 \\
3 \\
11 \\
8\end{array}$ & $\begin{array}{r}81 \\
104 \\
61 \\
60 \\
177\end{array}$ & $\begin{array}{l}55 \\
21 \\
66 \\
54 \\
26\end{array}$ & $\begin{array}{r}3 \\
1 \\
3 \\
27 \\
5\end{array}$ & $\begin{array}{r}11 \\
1 \\
4 \\
4 \\
14\end{array}$ & $\begin{array}{l}4 \\
4 \\
8 \\
6\end{array}$ & $\begin{array}{l}2 \\
1 \\
2 \\
3 \\
3\end{array}$ & $\begin{array}{l}4 \\
3 \\
6\end{array}$ & $\begin{array}{l}2 \\
5 \\
1 \\
2\end{array}$ & $\vdots$ & $\vdots$ & $\begin{array}{l}2 \\
3 \\
7 \\
5 \\
5\end{array}$ & $\begin{array}{r}14 \\
7 \\
2 \\
\vdots\end{array}$ & $\therefore$ & i & $\begin{array}{l}344 \\
351 \\
317 \\
357 \\
498\end{array}$ \\
\hline $\begin{array}{l}2 \mathrm{H}-5.5-7 \\
2 \mathrm{H}-5.55-57 \\
2 \mathrm{H}-6.5-7 \\
2 \mathrm{H}-6.55-57 \\
2 \mathrm{H}-6.605-107\end{array}$ & $\begin{array}{l}12.27 \\
12.70 \\
13.53 \\
13.98 \\
14.47\end{array}$ & $\begin{array}{l}7.506 \\
7.785 \\
8.325 \\
8.618 \\
8.939\end{array}$ & $\begin{array}{l}191 \\
168 \\
165 \\
225 \\
231\end{array}$ & $\begin{array}{l}8 \\
2 \\
7 \\
8 \\
6\end{array}$ & $\begin{array}{r}52 \\
116 \\
66 \\
37 \\
77 \\
77\end{array}$ & $\begin{array}{l}26 \\
53 \\
46 \\
56 \\
31 \\
\end{array}$ & $\begin{array}{r}10 \\
2 \\
7 \\
9 \\
9 \\
\end{array}$ & $\begin{array}{l}i \\
i\end{array}$ & $\begin{array}{l}1 \\
6 \\
5 \\
2 \\
2 \\
2\end{array}$ & $\begin{array}{l}3 \\
1 \\
1 \\
3 \\
3\end{array}$ & $\begin{array}{l}1 \\
2 \\
5 \\
4 \\
3 \\
\end{array}$ & $:$ & $\vdots$ & $\vdots$ & $\begin{array}{l}5 \\
1 \\
9 \\
4 \\
\end{array}$ & i & : & : & $\begin{array}{l}297 \\
354 \\
311 \\
349 \\
363 \\
\end{array}$ \\
\hline $\begin{array}{l}2 \mathrm{H}-7.8-10 \\
3 \mathrm{H}-1.6-8 \\
3 \mathrm{H}-1,55-57 \\
3 \mathrm{H}-1,87-90 \\
3 \mathrm{H}-1.99-102\end{array}$ & $\begin{array}{l}14.97 \\
16.06 \\
16.52 \\
16.85 \\
16.97\end{array}$ & $\begin{array}{r}9.266 \\
9.982 \\
10.285 \\
10.496 \\
10.582\end{array}$ & $\begin{array}{l}266 \\
144 \\
184 \\
176 \\
135\end{array}$ & $\begin{array}{r}10 \\
6 \\
1 \\
5 \\
4\end{array}$ & $\begin{array}{l}59 \\
37 \\
19 \\
52 \\
34\end{array}$ & $\begin{array}{r}40 \\
78 \\
84 \\
74 \\
132 \\
\end{array}$ & $\begin{array}{r}8 \\
39 \\
22 \\
\vdots\end{array}$ & $\begin{array}{l}3 \\
i \\
i\end{array}$ & $\begin{array}{l}2 \\
3 \\
\vdots\end{array}$ & $\begin{array}{l}3 \\
i\end{array}$ & $\begin{array}{r}13 \\
i\end{array}$ & $:$ & $\vdots$ & i & $\begin{array}{l}1 \\
2 \\
3 \\
\end{array}$ & $\begin{array}{l}\mathrm{i} \\
\mathrm{i} \\
\mathrm{i}\end{array}$ & $\begin{array}{l}\mathrm{i} \\
\mathrm{i} \\
\mathrm{i}\end{array}$ & i & $\begin{array}{l}346 \\
325 \\
318 \\
311 \\
309 \\
\end{array}$ \\
\hline $\begin{array}{l}3 \mathrm{H}-1,104-106 \\
3 \mathrm{H}-2,4-6 \\
3 \mathrm{H}-2,13-16 \\
3 \mathrm{H}-2,55-57 \\
3 \mathrm{H}-2,105-107\end{array}$ & $\begin{array}{l}17.01 \\
17.51 \\
17.61 \\
18.02 \\
18.52\end{array}$ & $\begin{array}{l}10.609 \\
10.939 \\
11.000 \\
11.277 \\
11.609 \\
\end{array}$ & $\begin{array}{l}129 \\
225 \\
192 \\
125 \\
113\end{array}$ & $\begin{array}{r}4 \\
5 \\
11 \\
13 \\
32 \\
\end{array}$ & $\begin{array}{r}33 \\
74 \\
74 \\
164 \\
143 \\
\end{array}$ & $\begin{array}{r}89 \\
35 \\
11 \\
2 \\
\end{array}$ & $\begin{array}{r}17 \\
1 \\
\vdots \\
\end{array}$ & i & $\begin{array}{l}1 \\
1 \\
3 \\
9 \\
2 \\
\end{array}$ & $\begin{array}{l}8 \\
2 \\
i\end{array}$ & $\begin{array}{l}2 \\
1 \\
i\end{array}$ & $\begin{array}{l}i \\
i \\
\end{array}$ & : & $\therefore$ & $\begin{array}{l}5 \\
4 \\
4 \\
1 \\
2\end{array}$ & : & : & : & $\begin{array}{l}288 \\
348 \\
297 \\
311 \\
298 \\
\end{array}$ \\
\hline $\begin{array}{l}3 \mathrm{H}-2.124-127 \\
3 \mathrm{H}-2.128-130 \\
3 \mathrm{H}-3,147-149 \\
3 \mathrm{H}-5,5-7 \\
3 \mathrm{H}-5,9-12\end{array}$ & $\begin{array}{l}18.72 \\
18.75 \\
20.39 \\
21.90 \\
21.95 \\
\end{array}$ & $\begin{array}{l}11.741 \\
11.761 \\
12.854 \\
13.864 \\
13.898\end{array}$ & $\begin{array}{l}104 \\
133 \\
146 \\
147 \\
161\end{array}$ & $\begin{array}{r}31 \\
39 \\
23 \\
5 \\
5\end{array}$ & $\begin{array}{r}161 \\
163 \\
99 \\
76 \\
100\end{array}$ & $\begin{array}{r}5 \\
7 \\
38 \\
84 \\
56\end{array}$ & $\begin{array}{r}i \\
14\end{array}$ & : & $\begin{array}{l}2 \\
7 \\
\vdots\end{array}$ & i & i & $:$ & : & : & $\begin{array}{l}3 \\
5 \\
5 \\
1 \\
1 \\
2\end{array}$ & i & $:$ & $\vdots$ & $\begin{array}{l}324 \\
354 \\
312 \\
331 \\
300 \\
\end{array}$ \\
\hline $\begin{array}{l}3 \mathrm{H}-5,28-30 \\
3 \mathrm{H}-5,53-55 \\
3 \mathrm{H}-5,86-88 \\
3 \mathrm{H}-6,7-9 \\
3 \mathrm{H}-6,55-57\end{array}$ & $\begin{array}{l}22.13 \\
22.36 \\
22.58 \\
23.29 \\
23.71\end{array}$ & $\begin{array}{l}14.014 \\
14.164 \\
14.320 \\
14.791 \\
15.081\end{array}$ & $\begin{array}{r}95 \\
135 \\
129 \\
58 \\
87\end{array}$ & $\begin{array}{r}4 \\
1 \\
2 \\
0 \\
10\end{array}$ & $\begin{array}{r}79 \\
102 \\
140 \\
149 \\
179\end{array}$ & $\begin{array}{r}76 \\
9 \\
153 \\
146 \\
128\end{array}$ & $\begin{array}{l}2 \\
0 \\
1 \\
4 \\
1 \\
\end{array}$ & $\begin{array}{l}4 \\
1 \\
0 \\
7 \\
.\end{array}$ & $\begin{array}{l}0 \\
1 \\
3 \\
5 \\
4 \\
\end{array}$ & $\begin{array}{r}3 \\
5 \\
12 \\
3 \\
\end{array}$ & $\begin{array}{l}1 \\
1 \\
7 \\
2 \\
1\end{array}$ & $\begin{array}{l}2 \\
1 \\
0 \\
2\end{array}$ & $\begin{array}{l}4 \\
3 \\
5 \\
5 \\
.\end{array}$ & $\begin{array}{l}1 \\
0 \\
0 \\
0 \\
.\end{array}$ & $\begin{array}{l}6 \\
2 \\
4 \\
5 \\
1 \\
\end{array}$ & $\begin{array}{l}0 \\
0 \\
0 \\
0 \\
.\end{array}$ & $\begin{array}{l}2 \\
0 \\
0 \\
2 \\
\text {. }\end{array}$ & $\begin{array}{l}0 \\
0 \\
0 \\
0 \\
.\end{array}$ & $\begin{array}{l}279 \\
261 \\
456 \\
389 \\
411\end{array}$ \\
\hline $\begin{array}{l}4 \mathrm{H}-1,5-7 \\
4 \mathrm{H}-1,32-34 \\
4 \mathrm{H}-1.86-88 \\
4 \mathrm{H}-1,105-107 \\
4 \mathrm{H}-2,55-57\end{array}$ & $\begin{array}{l}25.55 \\
25.82 \\
26.13 \\
26.32 \\
27.25\end{array}$ & $\begin{array}{l}16.323 \\
16.506 \\
16.738 \\
16.844 \\
17.475\end{array}$ & $\begin{array}{r}211 \\
25 \\
9 \\
5 \\
27\end{array}$ & $\begin{array}{r}7 \\
83 \\
74 \\
177 \\
190\end{array}$ & $\begin{array}{l}63 \\
81 \\
71 \\
85 \\
44\end{array}$ & $\begin{array}{r}7 \\
34 \\
78 \\
36 \\
46\end{array}$ & $\begin{array}{l}i \\
0 \\
0 \\
.\end{array}$ & $\begin{array}{l}i \\
0 \\
0 \\
.\end{array}$ & $\begin{array}{l}4 \\
2 \\
3 \\
4 \\
2\end{array}$ & $\begin{array}{l}0 \\
0 \\
0 \\
.\end{array}$ & $\begin{array}{l}0 \\
1 \\
1 \\
1\end{array}$ & $\begin{array}{l}0 \\
1 \\
0 \\
.\end{array}$ & $\begin{array}{l}\mathrm{i} \\
0 \\
0 \\
.\end{array}$ & $\begin{array}{l}0 \\
0 \\
1 \\
1\end{array}$ & $\begin{array}{l}2 \\
7 \\
1 \\
6 \\
6\end{array}$ & $\begin{array}{l}0 \\
0 \\
0 \\
\end{array}$ & $\begin{array}{l}0 \\
0 \\
0 \\
0\end{array}$ & $\begin{array}{l}0 \\
0 \\
0 \\
2\end{array}$ & $\begin{array}{l}294 \\
236 \\
238 \\
315 \\
318\end{array}$ \\
\hline $\begin{array}{l}4 \mathrm{H}-3,7-9 \\
4 \mathrm{H}-3,106-108 \\
4 \mathrm{H}-4,57-59 \\
4 \mathrm{H}-5,9-11 \\
4 \mathrm{H}-6,57-59\end{array}$ & $\begin{array}{l}28.23 \\
29.16 \\
30.12 \\
30.91 \\
32.78\end{array}$ & $\begin{array}{l}18.142 \\
18.775 \\
19.431 \\
19.971 \\
21.253\end{array}$ & $\begin{array}{r}4 \\
22 \\
30 \\
17 \\
18\end{array}$ & $\begin{array}{l}174 \\
193 \\
170 \\
198 \\
109\end{array}$ & $\begin{array}{l}25 \\
78 \\
81 \\
61 \\
60\end{array}$ & $\begin{array}{r}42 \\
10 \\
1 \\
1 \\
84\end{array}$ & $\begin{array}{l}0 \\
\mathrm{i}\end{array}$ & $\begin{array}{l}0 \\
\vdots \\
7\end{array}$ & $\begin{array}{l}7 \\
i \\
3\end{array}$ & $\begin{array}{l}0 \\
i \\
\text { i }\end{array}$ & $\begin{array}{l}0 \\
i \\
\vdots\end{array}$ & $\begin{array}{l}0 \\
\vdots \\
\end{array}$ & $\begin{array}{l}0 \\
\vdots\end{array}$ & $\begin{array}{l}0 \\
\vdots\end{array}$ & $\begin{array}{r}6 \\
8 \\
6 \\
11 \\
4\end{array}$ & $\begin{array}{l}0 \\
\vdots \\
\vdots\end{array}$ & $\begin{array}{l}0 \\
\vdots \\
\vdots\end{array}$ & $\begin{array}{l}0 \\
:\end{array}$ & $\begin{array}{l}258 \\
311 \\
292 \\
303 \\
302\end{array}$ \\
\hline $\begin{array}{l}4 \mathrm{H}-7,3-5 \\
5 \mathrm{H}-1,105-107 \\
5 \mathrm{H}-3,5-7 \\
5 \mathrm{H}-5,105-107 \\
5 \mathrm{H}-7,5-7\end{array}$ & $\begin{array}{l}33.68 \\
36.01 \\
37.73 \\
41.44 \\
43.11\end{array}$ & $\begin{array}{l}21.871 \\
23.477 \\
24.666 \\
27.243 \\
28.407\end{array}$ & $\begin{array}{r}28 \\
33 \\
8 \\
36 \\
105\end{array}$ & $\begin{array}{r}146 \\
123 \\
204 \\
99 \\
57\end{array}$ & $\begin{array}{l}59 \\
77 \\
52 \\
38 \\
38\end{array}$ & $\begin{array}{r}33 \\
51 \\
39 \\
116 \\
50\end{array}$ & $\begin{array}{r}23 \\
3 \\
9 \\
9 \\
3 \\
\end{array}$ & : & $\begin{array}{r}10 \\
7 \\
2 \\
6\end{array}$ & $\begin{array}{l}2 \\
i \\
4\end{array}$ & $\vdots$ & $:$ & $:$ & $:$ & $\begin{array}{l}5 \\
4 \\
1 \\
4 \\
5\end{array}$ & $\therefore$ & : & $\therefore$ & $\begin{array}{l}306 \\
291 \\
320 \\
305 \\
268\end{array}$ \\
\hline $\begin{array}{l}6 \mathrm{H}-1.97-99 \\
6 \mathrm{H}-2,55-57 \\
6 \mathrm{H}-4,53-55 \\
6 \mathrm{H}-5,105-107 \\
7 \mathrm{H}-2,5-7\end{array}$ & $\begin{array}{l}45.28 \\
46.02 \\
48.75 \\
50.70 \\
54.10\end{array}$ & $\begin{array}{l}30.414 \\
30.947 \\
32.911 \\
34.314 \\
36.760\end{array}$ & $\begin{array}{l}25 \\
20 \\
35 \\
53 \\
74\end{array}$ & $\begin{array}{r}129 \\
93 \\
39 \\
41 \\
33\end{array}$ & $\begin{array}{r}52 \\
35 \\
188 \\
148 \\
100\end{array}$ & $\begin{array}{r}76 \\
118 \\
23 \\
40 \\
58\end{array}$ & $\begin{array}{r}22 \\
14 \\
1 \\
5 \\
3\end{array}$ & : & $\begin{array}{r}10 \\
9 \\
15 \\
10 \\
36\end{array}$ & i & $\begin{array}{l}i \\
i \\
i\end{array}$ & : & $:$ & : & $\begin{array}{l}4 \\
8 \\
i \\
4\end{array}$ & i & : & i & $\begin{array}{l}319 \\
298 \\
301 \\
300 \\
303\end{array}$ \\
\hline $\begin{array}{l}7 \mathrm{H}-4.8-10 \\
7 \mathrm{H}-4,105-107 \\
7 \mathrm{H}-6,105-107 \\
7 \mathrm{H}-8,5-7 \\
8 \mathrm{H}-2,5-7\end{array}$ & $\begin{array}{l}56.31 \\
57.04 \\
60.06 \\
62.01 \\
63.70\end{array}$ & $\begin{array}{l}38.350 \\
38.876 \\
41.049 \\
42.452 \\
43.668\end{array}$ & $\begin{array}{r}19 \\
4 \\
11 \\
147 \\
21\end{array}$ & $\begin{array}{r}192 \\
155 \\
149 \\
17 \\
93\end{array}$ & $\begin{array}{l}95 \\
39 \\
95 \\
99 \\
15\end{array}$ & $\begin{array}{r}40 \\
2 \\
11 \\
28 \\
149\end{array}$ & $\begin{array}{r}3 \\
0 \\
0 \\
4 \\
14 \\
\end{array}$ & : & $\begin{array}{l}2 \\
3 \\
5 \\
6 \\
.\end{array}$ & i & $\begin{array}{l}i \\
i\end{array}$ & $\vdots$ & : & : & $\begin{array}{l}4 \\
7 \\
5 \\
2 \\
4 \\
\end{array}$ & i. & : & : & $\begin{array}{l}355 \\
211 \\
277 \\
308 \\
296\end{array}$ \\
\hline $\begin{array}{l}8 \mathrm{H}-4,5-7 \\
8 \mathrm{H}-4,105-107 \\
9 \mathrm{H}-1,104-106 \\
9 \mathrm{H}-2,58-60 \\
9 \mathrm{H}-3,5-7\end{array}$ & $\begin{array}{l}66.12 \\
66.87 \\
73.89 \\
74.80 \\
75.60\end{array}$ & $\begin{array}{l}45.409 \\
45.949 \\
51.000 \\
51.767 \\
52.442\end{array}$ & $\begin{array}{l}19 \\
30 \\
19 \\
39 \\
54\end{array}$ & $\begin{array}{r}177 \\
148 \\
137 \\
67 \\
72\end{array}$ & $\begin{array}{r}57 \\
109 \\
117 \\
149 \\
108\end{array}$ & $\begin{array}{l}18 \\
11 \\
15 \\
32 \\
70\end{array}$ & $\begin{array}{l}3 \\
4 \\
\vdots\end{array}$ & : & $\begin{array}{r}4 \\
6 \\
5 \\
25 \\
8\end{array}$ & $\begin{array}{l}3 \\
5 \\
2 \\
2\end{array}$ & i & 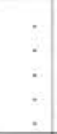 & $\dot{.}$ & i. & $\begin{array}{l}4 \\
2 \\
6 \\
.\end{array}$ & : & : & $:$ & $\begin{array}{l}278 \\
311 \\
305 \\
319 \\
314\end{array}$ \\
\hline $\begin{array}{l}9 \mathrm{H}-4,58-60 \\
9 \mathrm{H}-5,3-5\end{array}$ & $\begin{array}{l}77.30 \\
78.16\end{array}$ & $\begin{array}{l}53.876 \\
54.601\end{array}$ & $\begin{array}{l}53 \\
19\end{array}$ & $\begin{array}{l}120 \\
145\end{array}$ & $\begin{array}{l}56 \\
40\end{array}$ & $\begin{array}{l}34 \\
40\end{array}$ & $\begin{array}{l}16 \\
12\end{array}$ & : & 4 & : & . & : & . & : & 2 & & : & . & $\begin{array}{l}285 \\
257\end{array}$ \\
\hline
\end{tabular}


Table 1 (continued).

\begin{tabular}{|c|c|c|c|c|c|c|c|c|c|c|c|c|c|c|c|c|c|c|c|}
\hline $\begin{array}{l}\text { Core, section, } \\
\text { interval }(\mathrm{cm})\end{array}$ & $\begin{array}{l}\text { Depth } \\
\text { (mbsf) }\end{array}$ & $\begin{array}{l}\text { Age } \\
\text { (ka) }\end{array}$ & 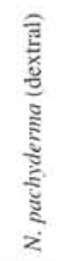 & 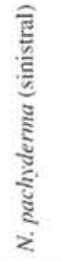 & 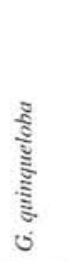 & 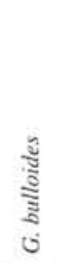 & 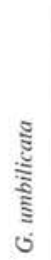 & 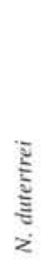 & $\begin{array}{l}\stackrel{\Xi}{\Xi} \\
\vdots \\
ن\end{array}$ & 仓 & 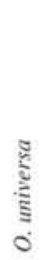 & $\underset{\Xi}{\stackrel{\Xi}{\Xi}}$ & 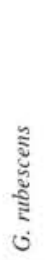 & 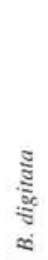 & $\begin{array}{c}\mathbb{Z} \\
\mathfrak{\Xi} \\
\mathfrak{\Xi} \\
0\end{array}$ & $\frac{\text { है }}{\text { हैँ }}$ & 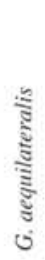 & & $\begin{array}{l}\text { Total } \\
\text { counts }\end{array}$ \\
\hline $\begin{array}{l}9 \mathrm{H}-7,38-40 \\
9 \mathrm{H}-7,138-140 \\
10 \mathrm{H}-1,108-110\end{array}$ & $\begin{array}{l}80.07 \\
81.02 \\
83.51 \\
\end{array}$ & $\begin{array}{l}56.212 \\
57.013 \\
59.113 \\
\end{array}$ & $\begin{array}{l}38 \\
75 \\
21 \\
\end{array}$ & $\begin{array}{r}90 \\
67 \\
143 \\
\end{array}$ & $\begin{array}{r}140 \\
31 \\
72 \\
\end{array}$ & $\begin{array}{r}43 \\
109 \\
56 \\
\end{array}$ & 12 & : & $\begin{array}{r}19 \\
11 \\
2\end{array}$ & i. & ! & $\therefore$ & : & : & $\begin{array}{r}15 \\
1\end{array}$ & $\vdots$ & : & : & $\begin{array}{l}344 \\
308 \\
295\end{array}$ \\
\hline $\begin{array}{l}10 \mathrm{H}-2,55-57 \\
10 \mathrm{H}-3,5-7 \\
10 \mathrm{H}-5,5-7 \\
10 \mathrm{H}-6,63-65 \\
11 \mathrm{H}-2,66-68 \\
\end{array}$ & $\begin{array}{l}84.41 \\
85.40 \\
88.45 \\
90.49 \\
94.05\end{array}$ & $\begin{array}{l}59.872 \\
60.707 \\
63.280 \\
65.000 \\
68.804 \\
\end{array}$ & $\begin{array}{l}27 \\
31 \\
22 \\
14 \\
18\end{array}$ & $\begin{array}{l}132 \\
175 \\
182 \\
188 \\
189\end{array}$ & $\begin{array}{l}44 \\
18 \\
40 \\
38 \\
41\end{array}$ & $\begin{array}{r}80 \\
116 \\
39 \\
53 \\
10\end{array}$ & $\begin{array}{r}17 \\
2 \\
2 \\
4 \\
\end{array}$ & : & $\begin{array}{l}2 \\
1 \\
7 \\
6 \\
4\end{array}$ & : & $\therefore$ & $\therefore$ & $\vdots$ & $\vdots$ & $\begin{array}{l}6 \\
\dot{4} \\
1\end{array}$ & $\vdots$ & : & : & $\begin{array}{l}303 \\
349 \\
292 \\
307 \\
263 \\
\end{array}$ \\
\hline $\begin{array}{l}11 \mathrm{H}-3,13-15 \\
11 \mathrm{H}-4,68-70 \\
11 \mathrm{H}-6,127-129 \\
12 \mathrm{H}-3,6-8 \\
13 \mathrm{H}-7,47-49\end{array}$ & $\begin{array}{r}95.01 \\
95.96 \\
99.68 \\
104.35 \\
118.53 \\
\end{array}$ & $\begin{array}{l}69.830 \\
70.845 \\
74.820 \\
79.810 \\
92.325 \\
\end{array}$ & $\begin{array}{r}13 \\
28 \\
12 \\
7 \\
5\end{array}$ & $\begin{array}{r}216 \\
52 \\
124 \\
235 \\
190\end{array}$ & $\begin{array}{r}46 \\
213 \\
123 \\
32 \\
68\end{array}$ & $\begin{array}{r}41 \\
9 \\
42 \\
18 \\
54\end{array}$ & $\begin{array}{l}5 \\
2 \\
2 \\
3\end{array}$ & $\begin{array}{l}i \\
i\end{array}$ & $\begin{array}{r}6 \\
3 \\
12 \\
3 \\
2 \\
\end{array}$ & $:$ & i & $\therefore$ & : & : & $\begin{array}{r}15 \\
i \\
4 \\
3\end{array}$ & $\vdots$ & : & : & $\begin{array}{l}342 \\
306 \\
316 \\
302 \\
326 \\
\end{array}$ \\
\hline $\begin{array}{l}13 \mathrm{H}-7,144-146 \\
13 \mathrm{H}-8,78-80 \\
14 \mathrm{H}-3,104-106 \\
14 \mathrm{H}-5,5-7 \\
15 \mathrm{H}-2,55-57\end{array}$ & $\begin{array}{l}119.50 \\
120.33 \\
124.60 \\
126.58 \\
131.74\end{array}$ & $\begin{array}{r}93.361 \\
94.248 \\
98.811 \\
100.927 \\
106.440\end{array}$ & $\begin{array}{r}4 \\
8 \\
7 \\
12 \\
10\end{array}$ & $\begin{array}{l}226 \\
175 \\
260 \\
290 \\
273\end{array}$ & $\begin{array}{r}24 \\
53 \\
5 \\
7\end{array}$ & $\begin{array}{r}56 \\
59 \\
90 \\
2 \\
42\end{array}$ & $\begin{array}{r}9 \\
7 \\
10\end{array}$ & : & $\begin{array}{l}2 \\
i \\
3\end{array}$ & $\therefore$ & $\therefore$ & $:$ & : & : & $\begin{array}{l}2 \\
2 \\
1 \\
3 \\
\end{array}$ & : & : & $\vdots$ & $\begin{array}{l}325 \\
304 \\
364 \\
307 \\
345\end{array}$ \\
\hline $\begin{array}{l}15 \mathrm{H}-3,11 \mathrm{I}-113 \\
15 \mathrm{H}-5,5-7 \\
15 \mathrm{H}-5,105-107 \\
15 \mathrm{H}-6,62-64 \\
15 \mathrm{H}-7,5-7\end{array}$ & $\begin{array}{l}133.84 \\
135.92 \\
136.92 \\
138.10 \\
139.02\end{array}$ & $\begin{array}{l}108.684 \\
110.906 \\
111.975 \\
113.236 \\
114.219 \\
\end{array}$ & $\begin{array}{r}102 \\
17 \\
89 \\
76 \\
81\end{array}$ & $\begin{array}{l}126 \\
268 \\
139 \\
165 \\
194 \\
\end{array}$ & $\begin{array}{r}54 \\
9 \\
52 \\
56 \\
21\end{array}$ & $\begin{array}{r}14 \\
2 \\
25 \\
11 \\
7\end{array}$ & $\begin{array}{l}3 \\
6 \\
6\end{array}$ & : & $\begin{array}{l}4 \\
3 \\
3 \\
8 \\
8\end{array}$ & i & $\vdots$ & $:$ & : & $:$ & $\begin{array}{l}2 \\
2 \\
1 \\
1\end{array}$ & $:$ & : & : & $\begin{array}{l}303 \\
298 \\
317 \\
318 \\
313 \\
\end{array}$ \\
\hline $\begin{array}{l}16 \mathrm{H}-1,105-107 \\
16 \mathrm{H}-2,55-57 \\
16 \mathrm{H}-3,5-7 \\
16 \mathrm{H}-3,114-116 \\
16 \mathrm{H}-4,66-68\end{array}$ & $\begin{array}{l}140.33 \\
141.24 \\
142.21 \\
143.30 \\
144.46\end{array}$ & $\begin{array}{l}115.619 \\
116.533 \\
117.473 \\
118.529 \\
119.653\end{array}$ & $\begin{array}{r}280 \\
199 \\
216 \\
259 \\
252\end{array}$ & $\begin{array}{r}27 \\
1 \\
14 \\
2 \\
4\end{array}$ & $\begin{array}{r}12 \\
6 \\
46 \\
8\end{array}$ & $\begin{array}{r}30 \\
110 \\
58 \\
5 \\
93\end{array}$ & $\begin{array}{r}17 \\
5\end{array}$ & $\begin{array}{l}4 \\
1 \\
3 \\
1 \\
8\end{array}$ & $\begin{array}{l}2 \\
2 \\
2 \\
4 \\
1\end{array}$ & $\begin{array}{l}1 . \\
3 \\
1\end{array}$ & $\begin{array}{l}1 \\
\vdots \\
4\end{array}$ & $\begin{array}{l}i \\
2 \\
\text {. }\end{array}$ & : & : & $\begin{array}{r}4 \\
10 \\
3 \\
3 \\
5\end{array}$ & 8 & : & : & $\begin{array}{l}349 \\
336 \\
326 \\
323 \\
396 \\
\end{array}$ \\
\hline $\begin{array}{l}16 \mathrm{H}-7.5-7 \\
17 \mathrm{H}-3,105-107 \\
17 \mathrm{H}-4,47-49 \\
17 \mathrm{H}-5,5-7 \\
17 \mathrm{H}-5,105-107 \\
17 \mathrm{H}-6,47-49 \\
18 \mathrm{H}-2,55-57 \\
18 \mathrm{H}-4,49-51 \\
18 \mathrm{H}-5,5-7 \\
19 \mathrm{H}-1,11-13\end{array}$ & $\begin{array}{l}148.38 \\
153.01 \\
154.01 \\
155.16 \\
156.16 \\
157.07 \\
160.45 \\
163.42 \\
164.48 \\
168.10\end{array}$ & $\begin{array}{l}122.994 \\
125.179 \\
125.651 \\
126.193 \\
126.665 \\
127.180 \\
130.224 \\
132.899 \\
133.854 \\
137.114 \\
\end{array}$ & $\begin{array}{r}230 \\
229 \\
240 \\
145 \\
131 \\
112 \\
76 \\
14 \\
2 \\
18 \\
\end{array}$ & $\begin{array}{r}8 \\
7 \\
5 \\
3 \\
7 \\
3 \\
24 \\
120 \\
173 \\
184 \\
\end{array}$ & $\begin{array}{r}16 \\
10 \\
8 \\
83 \\
69 \\
69 \\
75 \\
117 \\
135 \\
74 \\
52 \\
\end{array}$ & $\begin{array}{r}39 \\
38 \\
41 \\
65 \\
93 \\
89 \\
106 \\
33 \\
33 \\
67 \\
\end{array}$ & $\begin{array}{r}2 \\
13 \\
13 \\
18 \\
16 \\
2 \\
3\end{array}$ & $\begin{array}{l}i \\
i \\
\vdots\end{array}$ & $\begin{array}{r}\mathrm{i} \\
\mathrm{i} \\
\mathrm{i} \\
34 \\
1 \\
\mathrm{i}\end{array}$ & $\begin{array}{l}2 \\
3 \\
8 \\
3 \\
7 \\
9\end{array}$ & $\begin{array}{l}2 \\
5 \\
3 \\
i \\
4 \\
\vdots \\
i\end{array}$ & $\begin{array}{r}i \\
6 \\
1 \\
11 \\
3 \\
\vdots \\
i \\
1\end{array}$ & $\begin{array}{l}\vdots \\
\vdots\end{array}$ & $\begin{array}{l}\vdots \\
\vdots \\
\vdots\end{array}$ & $\begin{array}{r}7 \\
6 \\
8 \\
2 \\
4 \\
1 \\
7 \\
13 \\
4 \\
3 \\
3\end{array}$ & $\begin{array}{l}\vdots \\
i \\
i \\
\text { i }\end{array}$ & $\begin{array}{l}\vdots \\
\vdots \\
i \\
\vdots\end{array}$ & $\begin{array}{l}\vdots \\
\vdots \\
\vdots\end{array}$ & $\begin{array}{l}304 \\
304 \\
322 \\
302 \\
340 \\
317 \\
381 \\
319 \\
289 \\
329 \\
\end{array}$ \\
\hline $\begin{array}{l}19 \mathrm{H}-\mathrm{I}, 105-107 \\
19 \mathrm{H}-2,61-63 \\
20 \mathrm{H}-2,55-57 \\
20 \mathrm{H}-5,12-14 \\
21 \mathrm{H}-1,25-27\end{array}$ & $\begin{array}{l}169.03 \\
170.02 \\
179.39 \\
183.37 \\
187.25\end{array}$ & $\begin{array}{l}137.951 \\
138.843 \\
147.282 \\
150.866 \\
154.360\end{array}$ & $\begin{array}{r}2 \\
9 \\
15 \\
29 \\
7\end{array}$ & $\begin{array}{l}230 \\
259 \\
182 \\
183 \\
110\end{array}$ & $\begin{array}{l}51 \\
46 \\
51 \\
23 \\
68\end{array}$ & $\begin{array}{r}37 \\
8 \\
34 \\
58 \\
83\end{array}$ & $\begin{array}{r}2 \\
4 \\
4 \\
2 \\
45\end{array}$ & : & $\begin{array}{l}2 \\
4 \\
2 \\
3 \\
\end{array}$ & i. & : & $\begin{array}{l}\vdots \\
4 \\
\end{array}$ & : & : & $\begin{array}{r}4 \\
2 \\
16 \\
13 \\
3 \\
\end{array}$ & $\vdots$ & : & : & $\begin{array}{l}328 \\
329 \\
305 \\
313 \\
319 \\
\end{array}$ \\
\hline $\begin{array}{l}2 \mathrm{IH}-2,95-97 \\
2 \mathrm{IH}-3,45-47 \\
2 \mathrm{IH}-5,45-47 \\
2 \mathrm{IH}-5,145-147\end{array}$ & $\begin{array}{l}188.82 \\
189.98 \\
193.08 \\
194.08\end{array}$ & $\begin{array}{l}155.774 \\
156.819 \\
159.611 \\
160.230\end{array}$ & $\begin{array}{r}8 \\
9 \\
13 \\
10\end{array}$ & $\begin{array}{l}178 \\
102 \\
190 \\
199\end{array}$ & $\begin{array}{r}56 \\
58 \\
\\
\end{array}$ & $\begin{array}{r}61 \\
107 \\
43 \\
65\end{array}$ & $\begin{array}{l}38 \\
53 \\
76 \\
36\end{array}$ & : & $\begin{array}{l}3 \\
:\end{array}$ & i & : & $\therefore$ & : & : & $\begin{array}{l}3 \\
3 \\
4\end{array}$ & : & : & : & $\begin{array}{l}347 \\
332 \\
322 \\
315\end{array}$ \\
\hline
\end{tabular}

in Stage 1 and Substage 5e. This form also occurs sporadically in low frequencies during Stage 3 (55 to $25 \mathrm{ka}$ ) and glacial Stage $6(\sim 150$ ka). $G$. ruber is largely absent during the interval from $110 \mathrm{ka}$ (within Stage 5) to $60 \mathrm{ka}$ (Stage 4).

Neogloboquadrina dutertrei, another warm-water form, exhibits abundance peaks (up to $\sim 3 \%$ ) only during the extreme warm peaks represented by Stage 1 and Substage 5e (Fig. 7). This form is mostly absent in other intervals.

Globorotalia inflata responded as a warm-water form in Hole $893 \mathrm{~A}$, forming two main frequency peaks (up to $\sim 3 \%$ ) in Stage 1 and Substage 5 e (Fig. 7). Otherwise, this species is present only in a few intervals during Stage 6.

Orbulina universa, another warm-water species, also forms two main peaks (generally up to $2 \%$, with maximum of $4 \%$ ) associated with Stage 1 and Substage 5e (Fig. 7). This form is also present consistently, although in low abundances, during Stage 3. Other occurrences are minor.

The percentages of four relatively warm-water species in Santa Barbara Basin (G. ruber, N. dutertrei, G. inflata, and O. universa) oc- curring in low abundances are summed as a single group (termed warm forms) in Figures 7 and 8 . Frequency variation of this group reveals two peaks associated with Stage $I$ and Substage 5 e, with smaller peaks associated with Stage 3. A single anomalous sample with high relative abundance of the warm forms occurs during Stage 6 ( 150 ka). Other intervals exhibit low frequencies.

Two other planktonic forms that occur consistently, although in relatively low abundances $(<\sim 4 \%)$, in Hole $893 \mathrm{~A}$ are Globorotalia scitula and Globigerinita glutinata. Neither exhibits trends apparently related to climatic oscillations.

Detailed changes in N. pachyderma frequencies and coiling ratios for the last $20 \mathrm{ka}$ are shown in Figure 9 plotted against the oxygen isotopic record. The last glacial maximum ( 20 to $17 \mathrm{ka}$ ) is indicated by relatively high frequencies of sinistral-coiled $N$. pachyderma, low frequencies of dextral-coiled $N$. pachyderma, and high ratio of dextral to sinistral forms of $N$. pachyderma. An abrupt switch occurs to higher values of dextral-coiled $N$. pachyderma, low values of sinistral-coiled $N$. pachyderma, and a low ratio of dextral to sinistral forms of $N$. pachyderma between 17 and 16 ka during the early part 
Figure 3. Changes in Neogloboquadrina pachyderma characteristics with depth (in meters below seafloor) in Hole 893A. Santa Barbara Basin. Shown are percent frequency changes of dextral and sinistral forms of $N$. pachyderma in planktonic foraminiferal assemblages $(>150 \mu \mathrm{m})$ and of the percent of dextral-coiling forms within $N$. pachyderma populations.
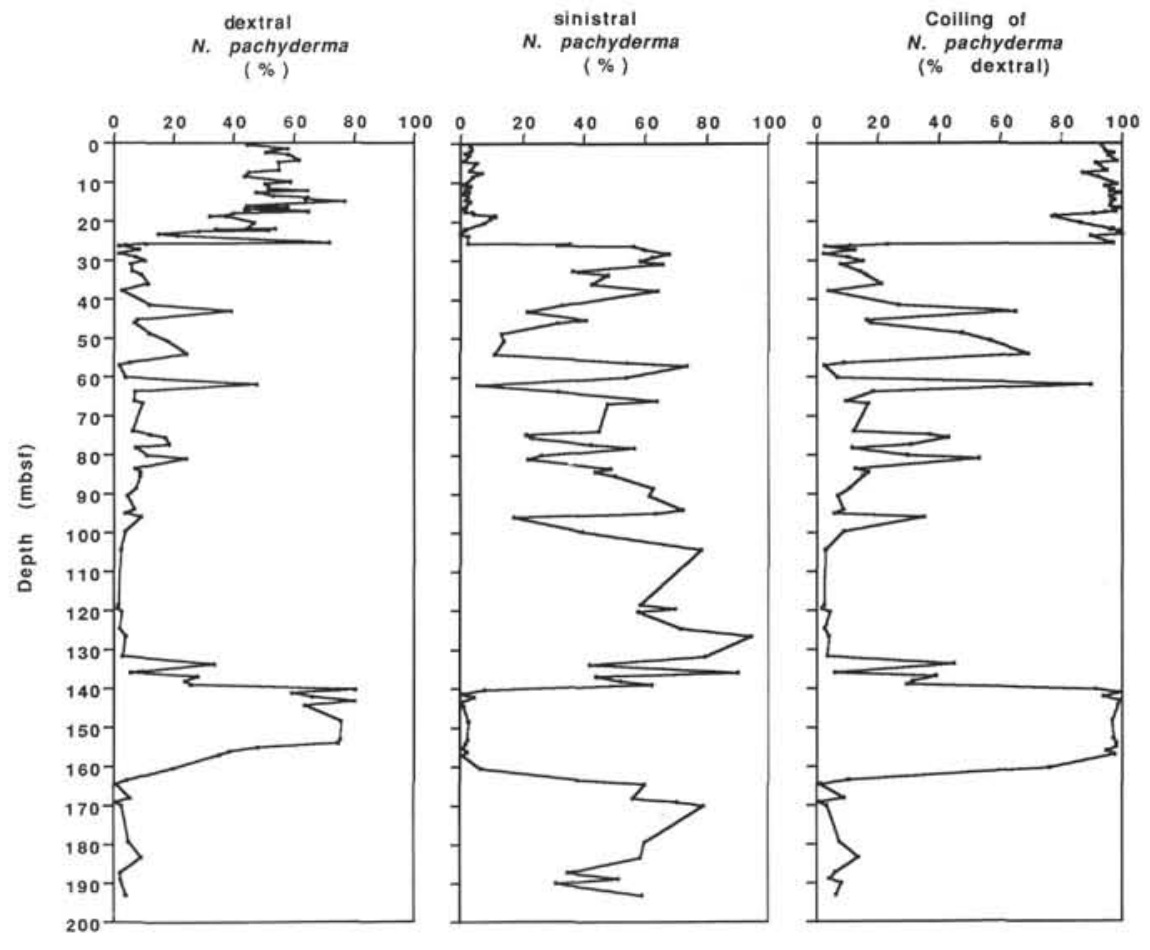

of Termination IA, as indicated by changes in oxygen isotopic values of the foraminifers. The last deglaciation (Termination I) between $\sim 16.5$ and $9 \mathrm{ka}$, as recorded by decreased $\delta^{18} \mathrm{O}$ foraminiferal values, exhibits a general upward increase in the relative frequencies of dextral-coiled $N$. pachyderma. A distinct reversal in these foraminiferal trends occurred between $\sim 13$ and $11.2 \mathrm{ka}$. This interval exhibits a $10 \%$ increase in sinistral-coiled $N$. pachyderma, a $10 \%$ decrease in dextral-coiled $N$. pachyderma, and a $20 \%$ reduction in dextral-coiled forms within N. pachyderma populations. These changes were associated with a temporary increase in $\delta^{18} \mathrm{O}$ values marking the Younger
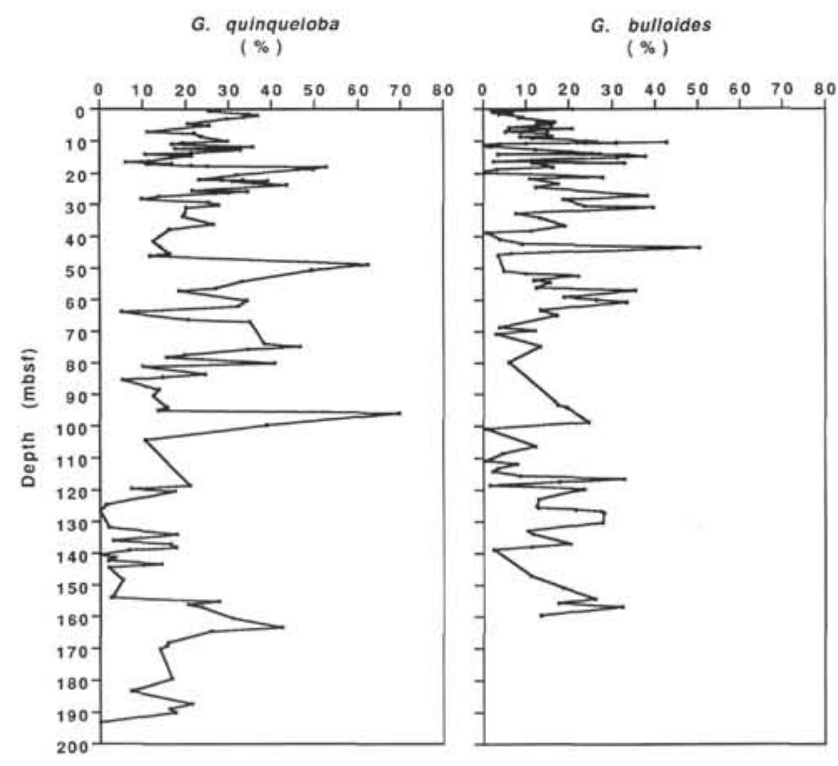

Figure 4. Percent frequency changes with depth of Globigerina quinqueloba and Globigerina bulloides within planktonic foraminiferal assemblages in Hole 893A.
Dryas cooling event. Other than during the Younger Dryas the percent frequency of sinistral-coiled $N$. pachyderma and coiling ratio changes exhibit little variation during the last $16.5 \mathrm{ka}$. Frequency variations shown by dextral-coiled $N$. pachyderma are significantly higher (from $40 \%$ to $80 \%$ ) during the interval representing the last 10 ka. Highest frequencies occur at $\sim 9$ ka (Fig. 9).

\section{DISCUSSION \\ Climatic History}

Comparisons between the oxygen isotopic record and changes in planktonic foraminiferal assemblages in Hole 893A clearly show that the assemblages responded to glacial/interglacial oscillations during the last $160 \mathrm{ka}$. Quantitatively, this is most clearly illustrated by changes in relative frequency of dextral and sinistral-coiled N. pachyderma and in the coiling ratio changes of this species. Cool-water assemblages were usually dominated by sinistral-coiled $N$. pachyderma, whereas warm-water assemblages were dominated by dextral-coiled $N$. pachyderma. Warm-water assemblages are also marked by a higher species diversity owing to the presence of several subtropical taxa. The presence of these subtropical forms clearly marks the peak warming intervals (Stage 1 and Substage 5e) of the last $160 \mathrm{ka}$. Changes in planktonic foraminiferal assemblage composition clearly define the warmest (Stage 1 and Substage 5e) and coolest (Stages 2, 4 and 6) intervals in the sequence. Interstadial Stage 3 is associated with planktonic foraminiferal assemblages that are at times intermediate in character between those of glacial and interglacial episodes.

In spite of these close relations, changes in the planktonic foraminiferal assemblages do not completely mirror the pattern of oxygen isotopic change. This is most clearly shown by the absence of a warm-water assemblage associated with the younger part of Stage 5 ( $5 \mathrm{c}$ to $5 \mathrm{a} ; 110$ to $70 \mathrm{ka}$ ). Instead, this warm interval is anomalous in its association with a cool-water assemblage dominated by sinistralcoiled $N$. pachyderma and almost complete lack of forms characteristic of warm waters. The dominance of a cool-water planktonic foraminiferal assemblage during an interglacial episode marked by 

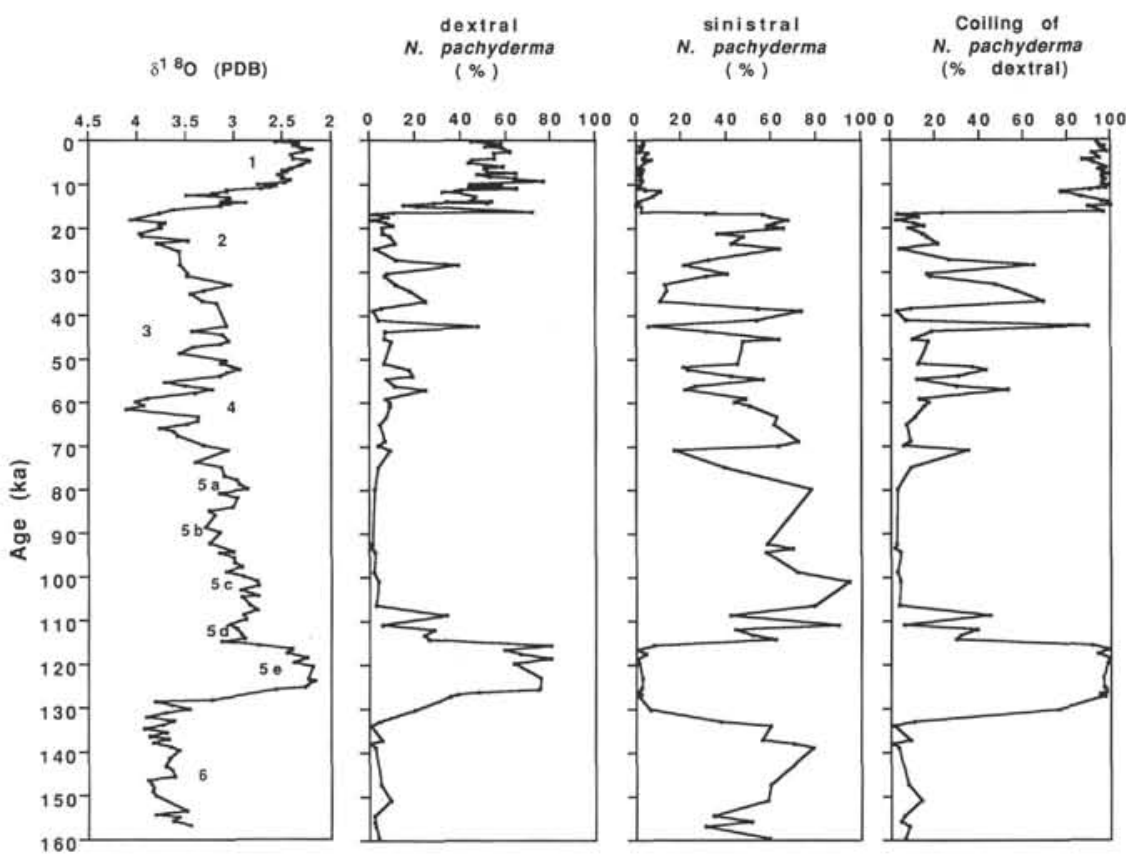

Figure 5. Changes in Neogloboquadrina pachyderma characteristics with age compared with oxygen isotope stratigraphy (Kennett, this volume) in Hole 893A. Shown are percent frequency changes of dextral and sinistral forms of $N$. pachyderma in planktonic foraminiferal assemblages $(>150 \mu \mathrm{m})$, percentage of dextral-coiling forms within N. pachyderma, and assigned oxygen isotopic stages for this 160-ka record.

relatively high oxygen isotopic temperatures is difficult to explain. One possibility is that dissolution increased abundances of the more dissolution-resistant sinistral forms relative to dextral forms of $N$. pachyderma (Sautter and Thunell, 1989). Although the planktonic foraminifers seem well preserved, much of this interval is marked by relatively low abundances of the dissolution-susceptible form $G$. quinqueloba (Figs. 2 and 4). On the other hand, the assemblages in this interval exhibit no increase in $N$. dutertrei, which would likely have been the case if they had been originally warm and subsequently modified by dissolution. Sautter and Thunell (1991) found that increased dissolution of planktonic foraminiferal assemblages in San Pedro Basin, Southern California, led to increased frequencies of $N$.
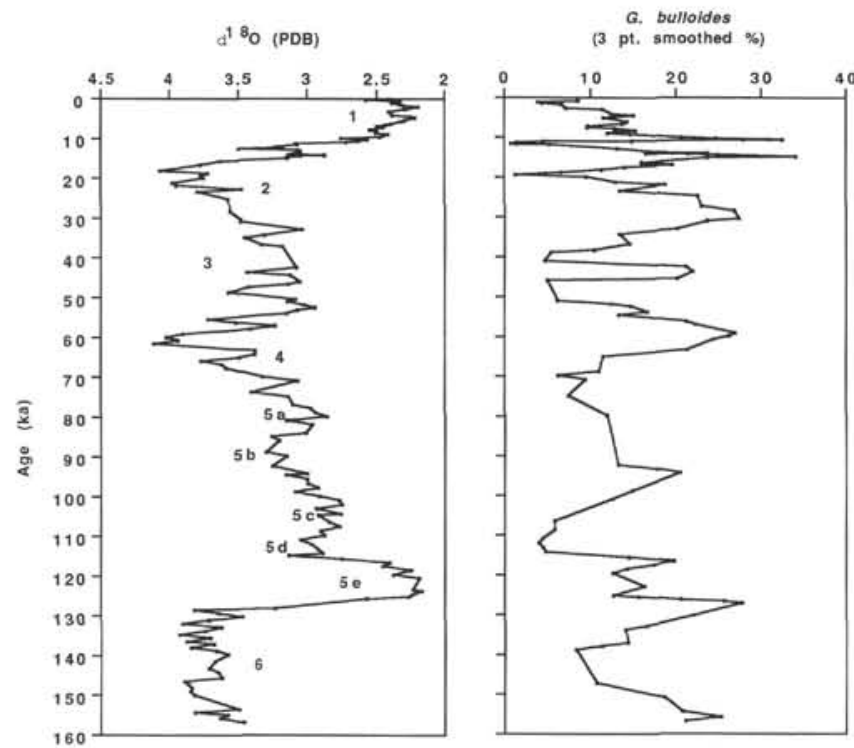

Figure 6. Percent frequency changes with age (ka) of Globigerina bulloides (smoothed using 3-point running average) within planktonic foraminiferal assemblages compared with oxygen isotopic stratigraphy (Kennett, this volume) in Hole 893A. The assignment of oxygen isotopic stages is indicated for this 160-ka record. dutertrei, a relatively robust warm-water taxon. The character of other microfossil groups in this interval may help resolve this problem.

Times of cool sea-surface temperatures in Santa Barbara Basin are associated with increased influence of the cool California Current and weakened northward flow of the warm Davidson Countercurrent. In contrast, episodes of relatively warm sea-surface temperatures in Santa Barbara Basin are associated with weakened southerly flow of the California Current. Quantitative changes in planktonic foraminiferal assemblages in Hole 893A during the late Quaternary reflect the changing relative strength of the California Current and Davidson Countercurrent. The sequence records the meridional movement within the California Current of the Subarctic and Transitional Water Masses and their associated planktonic assemblages over the northern part of the Southern California Borderland Province.

The two distinctly different assemblages marking these two surface-water masses are clearly marked by changes in dominance of sinistral-coiled relative to dextral-coiled $N$. pachyderma and other faunal characteristics. The present-day Transitional Assemblage in Santa Barbara Basin, dominated by dextral-coiled $N$. pachyderma, is characteristic of the warmest intervals of the late Quaternary in this region. These assemblages are associated with average modern seasurface temperatures in the basin of $\sim 15^{\circ} \mathrm{C}$ (range from $\sim 12^{\circ}$ to $17^{\circ} \mathrm{C}$ or even seasonally higher). Slightly warmer conditions occurred at times during the Holocene (Fig. 9), as suggested by the higher frequencies $(\sim 60 \%-70 \%)$ of dextral-coiled $N$. pachyderma compared with average late Holocene values $(\sim 40 \%-50 \%)$. Conditions were clearly warmer during much of the Eemian (Substage 5e; Figs. 2 and 4) based on changes in the faunal parameters. The distribution of modern planktonic foraminiferal assemblages in surface sediments and the water column in the northeast Pacific region have been inadequately described as a basis for detailed estimates of late Quaternary paleotemperature changes of surface waters in the basin. Relationships between assemblages and hydrographic properties, including upwelling, are insufficiently understood. However, it has been determined that Subarctic waters located north at $\sim 45^{\circ}-50^{\circ} \mathrm{N}$ in the northeast Pacific are associated with dominantly sinistral-coiled $N$. pachyderma (Bradshaw, 1959; Smith, 1964; Bandy, 1968; Sautter and Thunell, 1989; Ortiz and Mix, 1992). The biogeographic boundary associated with the switch from dominantly sinistral to dominantly dextral-coiled N. pachyderma closely coincides with the Subpolar 
Figure 7. Percent frequency changes with age (ka) of Globigerinoides ruber. Neogloboquadrina dutertrei. Globorotalia inflata, and Orbulina universa and the sum of these percentages shown as total warm forms within planktonic foraminiferal assemblages in Hole $893 \mathrm{~A}$.
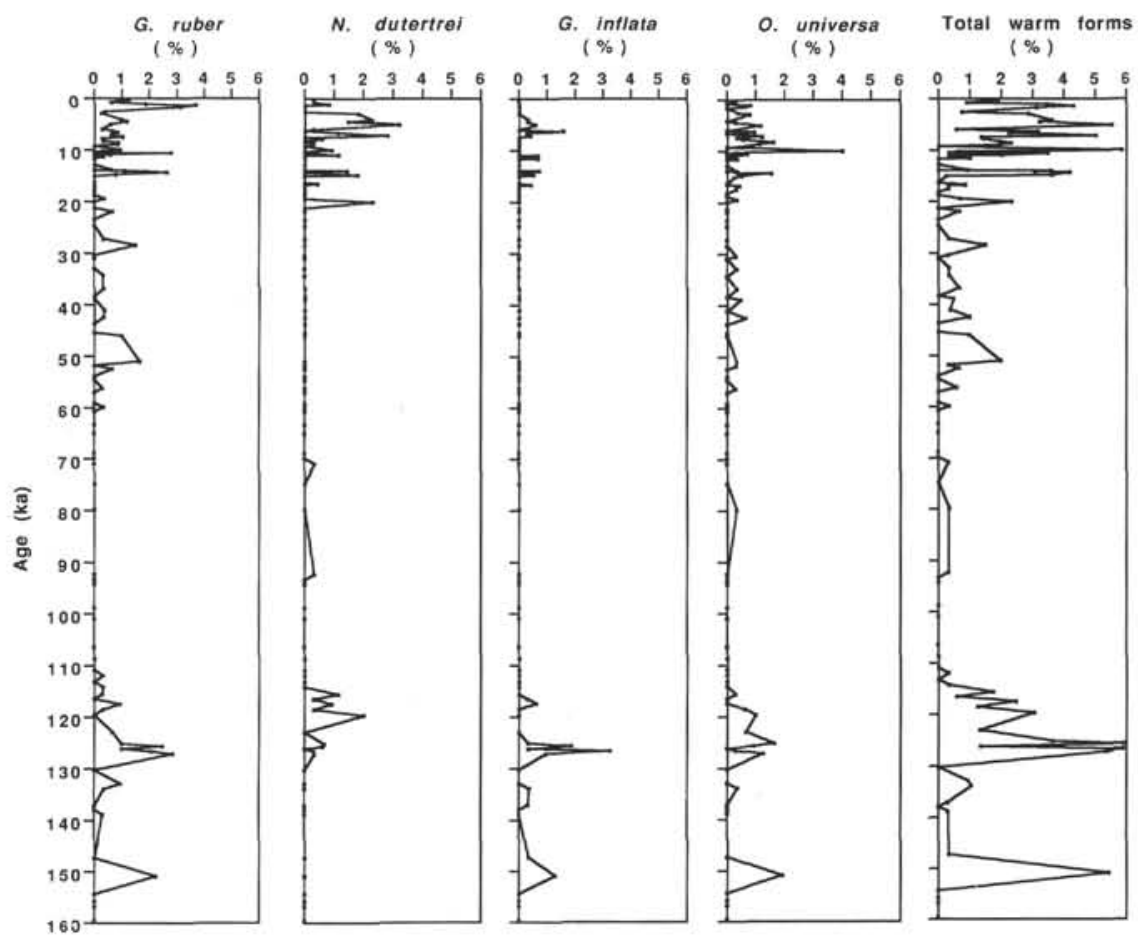

Front. This boundary also coincides with the $10^{\circ} \mathrm{C}$ summer isotherm. Cooling of surface to near-surface waters due to upwelling also causes major changes in planktonic foraminiferal assemblages (Ortiz and Mix, 1992). Hence, the relative abundance of sinistral-coiled $N$. pachyderma in coastal regions off Oregon results from a combination of influences of Subarctic Water and increased coastal upwelling (Ortiz and Mix, 1992). It appears, therefore, that the change in relative dominance of the two coiling forms of $N$. pachyderma occurs at $\sim 10^{\circ} \mathrm{C}$. Average minimal sea-surface temperatures in Hole $893 \mathrm{~A}$,
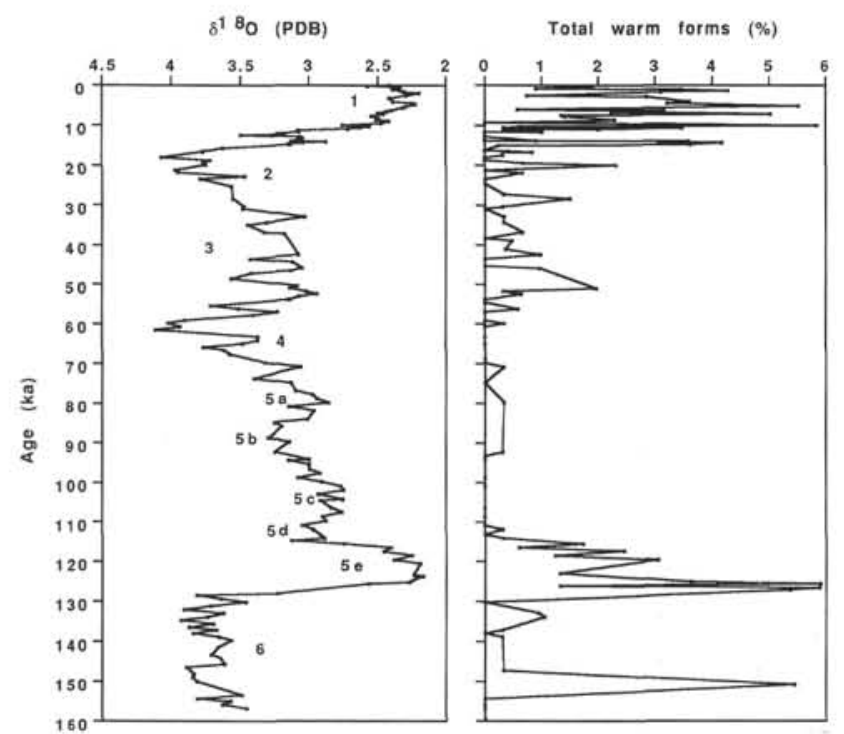

Figure 8. Percent frequency changes with age (ka) of species assigned as warm forms (see caption to Figure 7 for species included) within planktonic foraminiferal assemblages compared with oxygen isotopic stratigraphy (Kennett, this volume) in Hole 893A. The assignment of oxygen isotopic stages is indicated for this 160-ka record. such as occurred during glacial maxima, are difficult to estimate because of inadequate knowledge of modern regional distribution patterns of planktonic foraminifers. Subarctic faunal assemblages marked by sinistral coiling ratios of N. pachyderma higher than $90 \%$ are associated with even colder sea-surface temperatures. Estimates of $\sim 6^{\circ} \mathrm{C}$ have been suggested (Bandy, 1968; Bé, 1973) although the magnitude of glacial-interglacial $\delta^{18} \mathrm{O}$ change in planktonic foraminifers in Hole 893A (Kennett and Ingram, this volume) suggest that temperatures were no lower than $\sim 7^{\circ}-8^{\circ} \mathrm{C}$, values we adopt here.

Based on the assumption that these relationships between faunal and temperature changes are correct, average sea-surface temperatures in Santa Barbara Basin during the latest Quaternary ranged between $\sim 7^{\circ}$ and $8^{\circ} \mathrm{C}$ during glacial maxima and $15^{\circ} \mathrm{C}$ during peak interglacial episodes, including the present day. This provides a total minimum range of $7^{\circ}-8^{\circ} \mathrm{C}$ average temperatures for the latest Quarange between the glacial and interglacial maxima determined for the California Current region off northern Mexico (CLIMAP Project Members, 1976). peratures between glacial and interglacial episodes is less than the $11^{\circ} \mathrm{C}$ total recorded range in surface-water temperatures from 1952 to 1977 (Pisias, 1978). However, a smaller range is expected because our paleotemperature estimates represent average rather than extreme values. This is also smaller than the $12^{\circ} \mathrm{C}$ temperature range (February) estimated for the Holocene in the Santa Barbara Basin using changes in radiolarian assemblages (Pisias, 1978, 1979). The majority of samples in Hole 893A exhibit planktonic foraminiferal assemblages that represent two extremes within the Subarctic and Transitional Assemblages (Fig. 3). Most samples of Subarctic character are marked by $<10 \%$ dextral-coiled and $40 \%$ to $70 \%$ sinistralcoiled $N$. pachyderma. In addition the coiling ratios of $N$. pachyderma assemblages are $<10 \%$ dextral. In contrast, most assemblages identified as Transitional are marked by $50 \%$ to $70 \%$ dextral-coiled and $<5 \%$ sinistral-coiled $N$. pachyderma and a coiling ratio of $>90 \%$. The changes between these two extreme assemblages were usually rapid, although gradual at certain times. Gradual change is clearest during Termination II and at the end of Substage 5e (Fig. 5), but not ternary. This value is similar to the average sea-surface temperature

The total estimated range of $7^{\circ}-8^{\circ} \mathrm{C}$ in average sea-surface tem- 

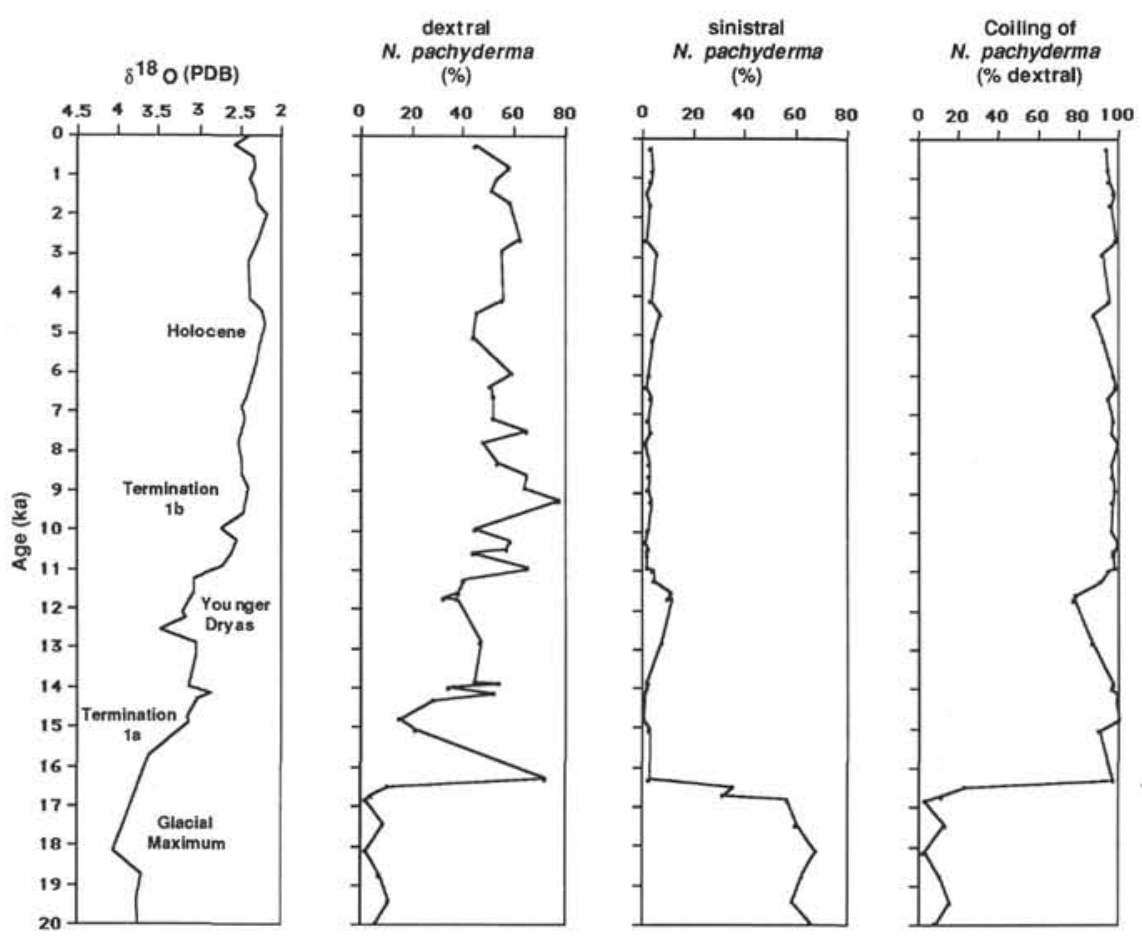

Figure 9. Details of changes in Neogloboquadrina pachyderma characteristics with age (k.y.) compared with oxygen isotopic stratigraphy for the last k.y. (Kennett, this volume) in Hole 893A. Shown are changes in percent frequency of dextral and sinistral forms of N. pachyderma in planktonic foraminiferal assemblages $(>150 \mu \mathrm{m})$ and the percentage of dextral-coiling forms within N. pachyderma. during Termination I. Changes between the two contrasting assemblages are evident during the last $20 \mathrm{ka}$ (Fig. 9) when the only interval marked by intermediate planktonic foraminiferal assemblages was during the Younger Dryas cooling ( 13 to $11.2 \mathrm{ka})$. Modest changes in the planktonic foraminiferal assemblages during this interval suggest relatively limited cooling of surface waters. The continued presence of the Transitional Assemblage during the Younger Dryas cooling indicates that Subarctic Water remained north of Southern California, and thus average surface-water temperatures in Santa Barbara Basin remained higher than $10^{\circ} \mathrm{C}$. Nevertheless, planktonic foraminiferal assemblages intermediate between those marking glacial and interglacial extremes suggest that the southern limit of Subarctic Water must have been nearby at this time. Oxygen isotopic values of planktonic foraminifers increased by $0.8 \%$ at this time reflecting a $\sim 3^{\circ} \mathrm{C}$ decrease in surface-water temperature, about one-half the change back to a full glacial episode (Kennett, this volume).

Subarctic planktonic foraminiferal assemblages in Hole 893A are associated with glacial Stages 2,4, and 6, which represent the coldest intervals of the sequence. During these intervals of intensification of the California Current, Subarctic waters migrated to the south of Santa Barbara Basin. Intensification of the California Current system during the last glacial maximum is recorded at least as far south as the Gulf of California (Molina-Cruz, 1988). In this region, changing latest Quaternary conditions were influenced more by the California Current than by changes in equatorial waters (Molina-Cruz, 1988). Subarctic assemblages also anomalously occur during the younger part of interglacial Stage 5 (Stage $5 \mathrm{c}$ to $5 \mathrm{a}$ ). The peak warming intervals, represented by the Transitional Assemblage, are associated with interglacial Stage 1 and Substage 5e. During these intervals Subarctic Water occurred far to the north of Santa Barbara Basin, as in the present day. The warm Davidson Countercurrent strongly influenced assemblages in the basin at these times, and increased surface-water stratification farther to the south in San Pedro Basin is marked by the presence of G. ruber (Sautter and Thunell, 1991). Stage 3 is the only prolonged interval marked by planktonic foraminiferal assemblages of intermediate character between the Subarctic and Transitional assemblages. The characteristics of the assemblage changes during Stage 3 suggest that Subarctic Water and the $10^{\circ} \mathrm{C}$ surface-water isotherm were at times close to Santa Barbara Basin. Changing relative strength of the California Current and the Davidson Countercurrent and also perhaps in coastal upwelling created the observed greater temporal variability in the assemblages during Stage 3 (Figs. 3 and $5)$. The significantly higher climatic variability exhibited during Stage 3 is similar to that previously described for the same interval in the Greenland Ice Sheet (Dansgaard et al., 1993). At other times, temperatures were significantly warmer or cooler than $10^{\circ} \mathrm{C}$ producing smaller temporal variability in the assemblages in Hole 893A.

During periods of intensification of the Davidson Countercurrent, warm surface-waters are transported northward to Santa Barbara Ba$\sin$. Although we have no modern planktonic foraminiferal data from Santa Barbara Basin, it is likely that it was only at these times that the subtropical form $G$. ruber is present in basin surface. The northward transport of warm water would have been especially strong during ENSO events. Therefore, it appears significant that $G$. ruber was found throughout much of the late Quaternary sequence in Hole $893 \mathrm{~A}$, although relative abundances are always low (Fig. 7). This species was not found during the last glacial maximum and the early part of the last deglaciation (19 to $14 \mathrm{ka}$ ), or during a prolonged interval from 110 to $60 \mathrm{ka}$. Otherwise, its distribution in Hole 893A suggests that warm-water influences from the south persisted in Santa Barbara Basin during much of the late Quaternary, including a number of cold intervals such as Stage 6. During these cold intervals, Subarctic Water had migrated to the Southern California region. The presence of $G$. ruber during such cool intervals may therefore represent evidence for anomalously warm events influencing surface waters of Santa Barbara Basin during much of the late Quaternary. Such extreme climatic episodes are likely to be those related to ENSO events. The stratigraphic record of $G$. ruber does not show simple relations with glacial/interglacial cycles (other than its consistent relative abundance with the peak warm intervals, Stage 1 and Substage 
$5 e$, but nevertheless it seems likely that higher resolution investigations will provide useful information on the changing influence of ENSO events in Southern California during the late Quaternary.

\section{Paleo-upwelling}

The Santa Barbara Basin experiences episodes of strong upwelling from late spring to early summer with individual upwelling events lasting up to several weeks related to changing strength of the California Current (Bakun, 1975; Eppley, 1986). It is generally considered that the presence of $G$. bulloides in significant numbers is an indication of oceanic upwelling (Thiede, 1975; Prell and Curry, 1981; Prell, 1984). For example, sediment trap studies in the San Pedro Basin to the southeast of Santa Barbara Basin (Sautter and Thunell. 1991; Sautter and Sancetta, 1992) indicate that G. bulloides increases to maximum production during strongest upwelling and is then the dominant foraminiferal taxon. Although this form exists over a wide range of oceanic environments and temperatures, it is most abundant in cool subtropical/transitional waters during times of upwelling (Sautter and Thunell, 1991). In Hole 893A, G. bulloides exhibits large fluctuations (up to $50 \%$ ) in relative abundance through the entire sequence. These fluctuations do not appear to be related to the late Quaternary climate cycles. If it is valid that increases in the abundance of $G$. bulloides represent evidence of significant upwelling, it follows that oceanic upwelling continually affected the Santa Barbara Basin during the late Quaternary. This appears to have occurred during both glacial and interglacial episodes. The severe restriction of the basin and increased isolation from the open ocean during glacial low stands of sea level (Fig. IB) did not reduce the productivity of this species.

\section{CONCLUSIONS}

1. Late Quaternary planktonic foraminiferal assemblages have been quantitatively analyzed in Hole $893 \mathrm{~A}$, a 196.5-m sequence in Santa Barbara Basin representing the last $\sim 160 \mathrm{ka}$. The faunas exhibit major oscillations in close association with interglacial/glacial cycles independently recognized using oxygen isotopic stratigraphy.

2. The sequence exhibits distinct oscillations between glacial and interglacial assemblages. Interglacial assemblages are moderately diverse and dominated by dextral-coiled N. pachyderma. These assemblages mark the Transitional Assemblage. Glacial assemblages exhibit much lower diversity and are dominated by sinistral-coiled $N$. pachyderma. This is the Subarctic Assemblage. In the modern ocean, the Transitional and Subarctic assemblages are associated with the $10^{\circ} \mathrm{C}$ summer isotherm.

3. Most of the sequence is represented by end-member Transitional and Subarctic assemblages. The Transitional Assemblage is associated with the warmest episodes that occurred during Stage I (Holocene) and Substage 5e (Eemian). The Subarctic Assemblage is associated with the coldest intervals represented by Stages 2, 4, and 6 , and also anomalously with a relatively warm interval during the younger part of Stage 5 ( $5 \mathrm{c}$ to $5 \mathrm{a}$ ). During these intervals, Subarctic waters $\left(<10^{\circ} \mathrm{C}\right)$ migrated to the south of Santa Barbara Basin. Stage 3 is the only prolonged interval marked by planktonic foraminiferal assemblages of intermediate character. At this time, Subarctic Water was close to the Santa Barbara region, and meridional changes in the $10^{\circ} \mathrm{C}$ isotherm caused high temporal variability in planktonic foraminiferal assemblages in Hole 893A.

4. Comparison with modern planktonic foraminiferal trends off western North America suggest that average sea-surface temperatures in Santa Barbara Basin varied between $\sim 7^{\circ}-8^{\circ} \mathrm{C}$ during glacial maxima to $\sim 15^{\circ} \mathrm{C}$ during interglacial maxima including the Holocene. However, the total paleotemperature range would have been greater than $7^{\circ}-8^{\circ} \mathrm{C}$.
5. Paleoclimate changes during the last 20 k.y. in Hole $893 \mathrm{~A}$ are well marked by quantitative changes in planktonic foraminiferal assemblages. The Subarctic Assemblage associated with the last glacial maximum is replaced, during Terminations $1 \mathrm{~A}$ and $1 \mathrm{~B}$, by the Transitional Assemblage characteristic of the Holocene. A significant temporary reversal toward cooler assemblages occurred during the Younger Dryas (13 to $11.2 \mathrm{ka}$ ). Surface-water temperatures at that time remained higher than $10^{\circ} \mathrm{C}$, although Subarctic Water was then probably located close to the Santa Barbara region.

6. Large frequency changes in Globigerina bulloides occurred throughout both glacial and interglacial intervals in Hole $893 \mathrm{~A}$. Because relatively high abundances of $G$. bulloides may represent evidence for significant oceanic upwelling, it is suggested that such upwelling continued in Santa Barbara Basin during both glacial and interglacial episodes.

\section{ACKNOWLEDGMENTS}

This research was supported by JOI/USSAC Grant Texas A\&M USSP008 and National Science Foundation Grant EAR-92-04857. We thank Karen Thompson and Staci Richard for valuable support in the laboratory. Also, thanks are extended to Ellen Kappel for her support and encouragement and to Greg Blake and UNOCAL Corporation for financial assistance. This paper was much improved as the result of useful suggestions made by Monty Graham and the reviewers, Alan Mix and Benjamin Flower. I thank them. Assistance from personnel in the Ocean Drilling Program has continued to be invaluable and is much appreciated.

\section{REFERENCES}

Addicott, W.O., 1969. Tertiary climatic changes in the marginal northeastern Pacific Ocean. Science, 165:583.

Atkinson, L.P., Brink, K.H., Davis, R.E., Jones, B.H., Paluszkiewicz, T.. and Stuart. D.W.. 1986. Mesoscale hydrographic variability in the vicinity of Points Conception and Arguello during April-May 1983: the OPUS 1983 experiment. J. Geophys. Res., 91:12899-12918.

Bakun, A., 1975. Daily and weekly upwelling indices, west coast of North America, 1967-1973. Natl. Oceanic Atmos. Adm. (U.S.), Spec. Sci. Rep._Fish.. 693.

Bandy, O.L., 1968. Paleoclimatology and Neogene planktonic foraminiferal zonation. G. Geol., 35:277-290.

1969. Relationships of Neogene planktonic foraminifera to paleoceanography and circulation. In Bronniman, P., and Renz, M.M. (Eds.), Proc. Ist Int. Conf. Planktonic Microfossils, Leiden, 1:46-57.

Bard, E., Hamelin, B., Fairbanks, R.G., and Zindler, A., 1990. Calibration of the ${ }^{14} \mathrm{C}$ time-scale over the past 30,000 years using mass spectrometric U-Th ages from Barbados corals. Nature, 345:405-410.

Bé, A.W.H.. 1973. Zoogeography of Antarctic and Subantarctic planktonic foraminifera in the Atlantic and Pacific Sectors. In Bushnell, V. (Ed.), Antarctic Map Folio Ser., Am. Geog. Soc., 17.

1977. An ecological, zoogeographic and taxonomic review of Recent planktonic foraminifera. In Ramsay, A.T.S. (Ed.), Oceamic Micropaleontology (Vol. 1): London (Acad. Press), 1-100.

Bradshaw, J.S., 1959. Ecology of living planktonic foraminifera in the North and Equatorial Pacific Ocean. Contrib. Cushman Found. Foraminiferal Res., 10:25-64.

CLIMAP Project Members, 1976. The surface of the ice-age Earth. Science, 191:1131-1137.

1981. Seasonal reconstructions of the Earth's surface at the last glacial maximum. Geol. Soc. Am.. Map and Chart Ser., MC36.

Dansgaard, W.. Johnsen. S.J., Clausen, H.B., Dahl-Jensen, D., Gundestrup, N.S., Hammer, C.U.. Hvidberg, C.S., Steffensen, J.P., Sveinbjörnsdottir, A.E., Jouzel, J., and Bond, G., 1993, Evidence for general instability of past climate from a 250-kyr ice-core record. Nature, 364:218-220.

Douglas, R., 198I. Paleoecology of continental margin basins: a modern case history from the borderland of Southern California. In Douglas. R., Gorsline, D.. and Colburn. I. (Eds.), Depositional Systems of Active Con- 
tinental Margin Basins. Soc. Econ. Paleontol. Mineral., Pacific Sect. Short Course, 121-156.

Dunbar, R.B.. 1983. Stable isotope record of upwelling and climate from Santa Barbara Basin, California. In Thiede, J., and Suess, E. (Eds.), Coastal Upwelling, Its Sediment Record, Part B. Sedimentary Records of Ancient Coastal Upwelling: New York (Plenum), 217-246.

Durham, J.W., 1950. Cenozoic marine climates of the Pacific Coast. Geol. Soc. Am. Bull., 61:1243.

Emery, K.O., 1960. The Sea Off Southern California: A Modern Habitat of Petroleum: New York (Wiley).

Enfield. D.B., and Allen. J.. 1980. On the structure and dynamics of monthly mean sea level anomalies along the Pacific Coast of North and South America. J. Plivs. Oceanogr., 10:557-578.

Eppley, R.W. (Ed.), 1986. Plankton dynamics of the Southern California Bight. Lect. Notes Coastal Estuarine Stud., 15.

Fairbanks, R.G., 1989. A 17,000-year glacio-eustatic sea level record: influence of glacial melting rates on the Younger Dryas event and deep-ocean circulation. Nature, 342:637-642.

Fairbanks, R.G., Sverdlove, M., Free. R., Wiebe, P.H., and Bé, A.W.H., 1982. Vertical distribution and isotopic fractionation of living planktonic foraminifera from the Panama Basin. Nature, 298:841-844.

Fairbanks, R.G., and Wiebe. P.H., 1980. Foraminifera and chlorophyll maximum: vertical distribution, seasonal succession, and paleoceanographic significance. Science, 209:1524-1526.

Heusser, L., 1978. Pollen in Santa Barbara Basin, California: a 12,000 year record. Geol. Soc. Am. Bull., 89:673-678.

Hickey, B.M., 1992. Circulation over the Santa Monica-San Pedro Basin and Shelf. Prog. Oceanogr., 30:37-115.

Huyer, A.. 1983. Coastal upwelling in the California Current system. Prog. Oceanogr., 12:259-284.

Ingle, J.C., Jr.. 1967. Foraminiferal biofacies variation and the MiocenePliocene boundary in Southern California. Bull. Am. Paleontol., 52:217394.

1973. Summary comments on Neogene biostratigraphy, physical stratigraphy, and paleo-oceanography in the marginal northeastern Pacific Ocean. In Kulm, L.D., von Huene, R., et al., Init. Repts. DSDP. 18: Washington (U.S. Govt. Printing Office), 949-960.

Kennett. J.P., 1968. Latitudinal variation in Globigerina pachyderma (Ehrenberg) in surface sediments of the southwest Pacific Ocean. Micropaleontology; 14:305-318.

1976. Phenotypic variation in some Recent and late Cenozoic planktonic foraminifera. In Hedley, R.H., and Adams, C.G. (Eds.), Foraminifera (Vol. 2): New York (Acad. Press), 111-170.

Kennett, J.P.. Baldauf. J.G., et al., 1994. Proc. ODP, Init. Repts., 146 (Pt. 2): College Station, TX (Ocean Drilling Program).

Lynn. R.J., and Simpson, J.J.. 1987. The California Current system: the seasonal variability of its physical characteristics. J. Geophys. Res., 92:12947-12966.

Martinson, D.G., Pisias, N.G., Hays, J.D., Imbrie, J., Moore, T.C., Jr., and Shackleton, N.J., 1987. Age dating and the orbital theory of the ice ages: development of a high-resolution 0 to 300,000-year chronostratigraphy. Quat. Res., 27:1-29.

McGowan, J.A., 1984. The California EI Niño-1983. Oceanus, 27:48-5I.

Molina-Cruz. A., 1988. Late Quaternary oceanography of the mouth of the Gulf of California: the polycystine connection. Paleoceanography, 3:447-459.

Moore. T.C.. Jr., 1973. Late Pleistocene-Holocene oceanographic changes in the northeastern Pacific. Quat. Res., 3:99-109.

- 1978. The distribution of radiolarian assemblages in the modern and ice-age Pacific. Mar. Micropaleontol., 3:229-266.

Namias, J., 1969. Use of sea-surface temperature in long-range predictions. WMO Technical Note 103. In Sea-Surface Temperatures. World Meteorological Organization, 247:1-18.
Ortiz, J.D., and Mix, A.C., 1992. The spacial distribution and seasonal succession of planktonic foraminifera in the California Current off Oregon, September 1987-September 1988. In Summerhayes, C.P., Prell, W.L., and Emeis, K.C. (Eds.), Upwelling Systems: Evolution Since the Early Miocene. Geol. Soc. Spec. Publ. London, 64:197-213.

Pisias, N.G., 1978. Paleoceanography of the Santa Barbara Basin during the last 8000 years. Quat. Res., 10:366-384.

1979. Model for paleoceanographic reconstructions of the California Current during the last 8000 years. Quat. Res., 11:373-386.

Prell, W.L., 1984. Variation of monsoonal upwelling: a response to changing solar radiation. In Hansen, J.E., and Takahashi, T. (Eds.), Climatic Processes and Climate Sensitivity. Geophys. Monogr., Am. Geophys. Union, Maurice Ewing Ser., 29:48-57.

Prell, W.L., and Curry, W.B., 1981. Faunal and isotopic indices of monsoonal upwelling: western Arabian Sea. Oceanol. Acta, 4:91-98.

Reid, J.L., Jr., Roden. G.I., and Wyllie, J.G., I958. Studies of the California Current system. Calif. Coop. Oceanic Fisheries Invest. Rep., 6:27-56.

Reimers, C.E., Lange, C.B., Tabak, M.. and Bernhard, J.M.. 1990. Seasonal spillover and varve formation in the Santa Barbara Basin. California. Limnol. Oceanogr., 35:1577-1585.

Reynolds, L., and Thunell, R.C., 1985. Seasonal succession of planktonic foraminifera in the subpolar North Pacific. J. Foraminiferal Res., $15: 282-301$

Robles, J.Ma., and Marinone, S.G., 1987. Seasonal and interannual thermohaline variability in the Guaymas Basin of the Gulf of California. Cont. Shelf Res., 7:715-733.

Roden, G.I., 1977. Oceanic subarctic fronts of the Central Pacific: structure of and response to atmospheric forcing. J. Phys. Oceanogr.. 7:761-778.

Sautter, L.R., and Sancetta, C., 1992. Seasonal associations of phytoplankton and planktic foraminifera in an upwelling region and their contribution to the seafloor. Mar. Micropaleontol., 18:263-278.

Sautter, L.R., and Thunell, R.C., 1989. Seasonal succession of planktonic foraminifera: results from a four-year time-series sediment trap experiment in the northeast Pacific. J. Foraminiferal Res., 19:253-267.

1991. Planktonic foraminiferal response to upwelling and seasonal hydrographic conditions: sediment trap results from San Pedro Basin, Southern California Bight. J. Foraminiferal Res., 21:347-363.

Schimmelmann, A., and Tegner, M.J., 1991. Historical oceanographic events reflected in ${ }^{13} \mathrm{C}^{12} \mathrm{C}$ ratio of total organic carbon in Santa Barbara basin sediment, Global Biogeochem. Cycles, 5:173-188.

Sholkovitz, E.R., and Gieskes, J.M., 1971. A physical-chemical study of the flushing of the Santa Barbara Basin. Limnol. Oceanogr., 16:479-489.

Simpson, J.J., and Lynn, R.J., 1990. A mesoscale eddy dipole in the offshore California Current. J. Geophys. Res., 95:13009-13022.

Smith. A.B., 1964. Living planktonic foraminifera collected along an eastwest traverse in the North Pacific. Contrib. Cushman Found. Foraminiferal Res., 15:131-134.

Soutar, A.. and Crill, P.A., 1977. Sedimentation and climatic patterns in the Santa Barbara Basin during the 19th and 20th centuries. Geol. Soc. Am. Bull., 88:1161-1172.

Stuiver, M., and Braziunas, T.F., 1993. Modeling atmospheric ${ }^{14} \mathrm{C}$ influences and ${ }^{14} \mathrm{C}$ ages of marine samples to 10,000 BC. Radiocarbon, 35:137-189.

Thiede, J., 1975. Distribution of foraminifera in surface waters of a coastal upwelling area. Nature, 253:712-714.

Weinheimer, A.L., Carson, T.L.. Wigley, C.R., and Casey, R.E., 1986. Radiolarian responses to recent and Neogene California El Niño and anti-El Niño events. Palaeogeogr. Palaeoclimatol., Palaeoecol., 53:3-25.

\footnotetext{
Date of initial receipt: 2 September 1994

Date of acceptance: 20 March 1995

Ms 146SR-299
} 